\title{
SOEP
}

SOEPpapers

SOEPpapers
on Multidisciplinary Panel Data Research
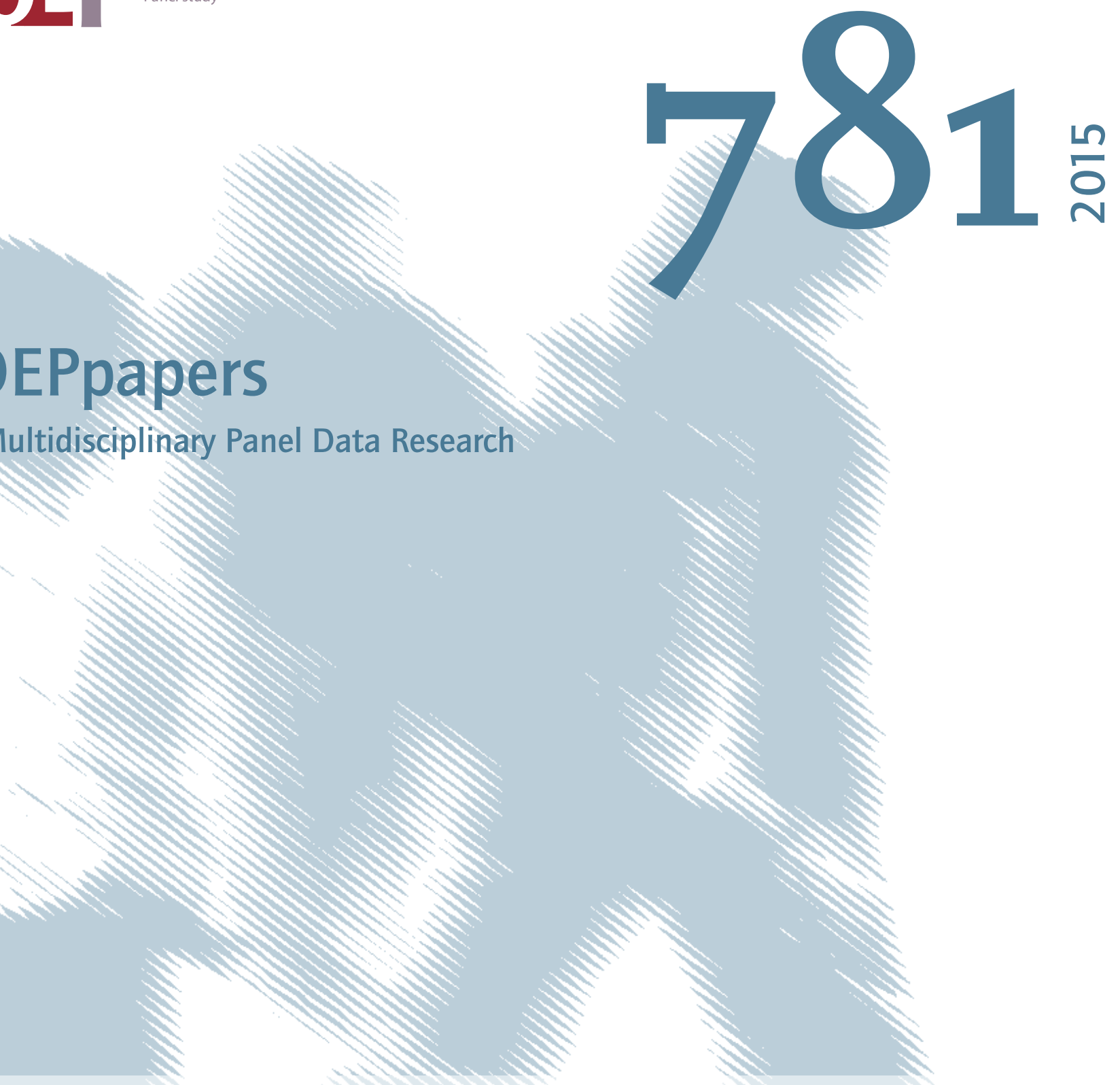

\section{Getting the Poor to Work: Three Welfare Increasing Reforms for a Busy Germany}


This series presents research findings based either directly on data from the German SocioEconomic Panel study (SOEP) or using SOEP data as part of an internationally comparable data set (e.g. CNEF, ECHP, LIS, LWS, CHER/PACO). SOEP is a truly multidisciplinary household panel study covering a wide range of social and behavioral sciences: economics, sociology, psychology, survey methodology, econometrics and applied statistics, educational science, political science, public health, behavioral genetics, demography, geography, and sport science.

The decision to publish a submission in SOEPpapers is made by a board of editors chosen by the DIW Berlin to represent the wide range of disciplines covered by SOEP. There is no external referee process and papers are either accepted or rejected without revision. Papers appear in this series as works in progress and may also appear elsewhere. They often represent preliminary studies and are circulated to encourage discussion. Citation of such a paper should account for its provisional character. A revised version may be requested from the author directly.

Any opinions expressed in this series are those of the author(s) and not those of DIW Berlin. Research disseminated by DIW Berlin may include views on public policy issues, but the institute itself takes no institutional policy positions.

The SOEPpapers are available at http://www.diw.de/soeppapers

\section{Editors:}

Jan Goebel (Spatial Economics)

Martin Kroh (Political Science, Survey Methodology)

Carsten Schröder (Public Economics)

Jürgen Schupp (Sociology)

Conchita D'Ambrosio (Public Economics)

Denis Gerstorf (Psychology, DIW Research Director)

Elke Holst (Gender Studies, DIW Research Director)

Frauke Kreuter (Survey Methodology, DIW Research Fellow)

Frieder R. Lang (Psychology, DIW Research Fellow)

Jörg-Peter Schräpler (Survey Methodology, DIW Research Fellow)

Thomas Siedler (Empirical Economics)

C. Katharina Spieß (Education and Family Economics)

Gert G. Wagner (Social Sciences)

ISSN: 1864-6689 (online)

German Socio-Economic Panel Study (SOEP)

DIW Berlin

Mohrenstrasse 58

10117 Berlin, Germany

Contact: Uta Rahmann | soeppapers@diw.de 


\title{
Getting the Poor to Work:
}

\section{Three Welfare Increasing Reforms for a Busy Germany*}

\author{
Robin Jessen $^{\dagger}$ \\ Davud Rostam-Afschar \\ Viktor Steiner $^{\S}$
}

July 22, 2015

\begin{abstract}
We study three budget-neutral reforms of the German tax and transfer system designed to improve work incentives for people with low incomes: a feasible flat tax reform that provides a basic income which is equal to the current level of the means tested unemployment benefit, and two alternative reforms that involve employment subsidies to stimulate participation and full-time work, respectively. We estimate labor supply reactions and welfare effects using a microsimulation model based on household data from the Socio-Economic Panel (SOEP) and a structural labor supply model. We find that all three reforms increase labor supply in the first decile of the income distribution. However, the flat tax scenario reduces overall labor supply by $4.9 \%$, the reform scenario designed to increase participation reduces labor supply by $1 \%$, while the reform that provides improved incentives to work full-time has negligible effects on overall labor supply. With equal welfare weights, aggregate welfare gains are realizable under all three reforms.
\end{abstract}

Keywords Flat Tax $\cdot$ Basic Income $\cdot$ Work Incentives $\cdot$ Poverty $\cdot$ Microsimulation

JEL Classification $\mathrm{H} 31 \cdot \mathrm{I} 38 \cdot \mathrm{J} 22 \cdot \mathrm{C} 25$

\footnotetext{
${ }^{*}$ We thank Juliane Hennecke, Johannes König, Lukas Mergele, Sebastian Schmitz, and seminar participants at the Berlin Labour Market Research Network (BeNA) for valuable comments. We thank the Hans-Böckler-Stiftung for financial support. The usual disclaimer applies.

†Department of Economics, Freie Universität Berlin, Boltzmannstr. 20, 14195 Berlin, Germany (e-mail: r.jessen@fu-berlin.de).

†Department of Economics, Freie Universität Berlin (e-mail: davud.rostam-afschar@fu-berlin.de).

${ }^{\S}$ Department of Economics, Freie Universität Berlin (e-mail: viktor.steiner@fu-berlin.de).
} 


\section{Introduction}

Countries that provide transfers to the unemployed face the problem well known as the equityefficiency-trade-off in the public economics literature. For instance, in Germany transfers are relatively generous (Franz et al. 2012), while withdrawal rates are very high and in some cases exceed $100 \%$. This implies strong disincentives for people with low earning perspectives to work. One frequently discussed way to improve these incentives is a flat tax scheme that implies lower withdrawal rates compared to the status quo. For Germany, a flat tax proposed in Kirchhof (2003) and in Kirchhof (2011) was part of the conservative election campaign in 2005. Such a flat tax is often coupled with some kind of basic income (Friedman 2002, among others). This might offset or reverse the incentives to work due to necessary tax increases if it is granted unconditionally and at a politically feasible level. ${ }^{1}$ The notion of basic income has become increasingly popular, for example Atkinson (2005) argues that the introduction of an unconditional basic income would eliminate the perverse disincentives brought about by social security benefits in combination with high transfer withdrawal rates. In addition, Colombino (2009) points out that unconditional basic income could be advantageous from the perspective of redistribution and cost-effectiveness. ${ }^{2}$ We analyze how such a reform scenario fares compared to two alternative scenarios that aim to improve work incentives for the poor. In contrast to other studies that investigate basic income schemes, we study a financially feasible scenario that we calibrate to be budget-neutral. We use the microsimulation model STSM for household data from the Socio-Economic Panel (SOEP) and estimate a structural labor supply model to calculate labor supply and welfare effects.

We contrast a flat tax/basic income reform (Flat Tax) to two alternative reform scenarios that aim to improve incentives by directly subsidizing employment exceeding specific thresholds of weekly working hours of people with low labor incomes - ten hours for the first reform (Employment) and 30 hours for the second reform (Full-Time). The first reform is financed by increasing marginal tax rates and abolishing social security exemptions for marginal employment while

\footnotetext{
${ }^{1}$ In Germany, such a basic income would only be in accordance with the constitution if it was at least as high as the subsistence level.

${ }^{2}$ Some examples how basic income works in practice are experiments from the US in New Jersey and Pennsylvania from 1968 to 1972, in Iowa and North Carolina from 1969 to 1973, in Gary, Indiana, between 1971 and 1974 , and in Seattle and Denver from 1971 to 1982 (Munnell 1987), in the Canadian city Dauphin from 1974 to 1978 (Prescott et al. 1986). A similar experiment providing a basic income of around 900 Euro per month is planned in Utrecht, set to begin in January 2016. In the same year, Switzerland is slated to hold a referendum on implementing basic income.
} 
the second reform is financed only through the abolishment of social security exemptions and increased marginal transfer withdrawal rates. The (Flat Tax) reform is a flat tax with marginal transfer withdrawal rates equal to the marginal tax rate and an unconditional basic income equal to the current subsistence level guaranteed through the means tested unemployment benefit (Unemployment Benefit II) and social assistance. ${ }^{3}$

Several kinds of employment subsidies have been discussed in the literature and among practitioners. Subsidies to social security contributions (SSC) for workers who work at least a specific number of hours per week have been in place in Belgium (Bonus a l'emploi, an employment subsidy for full-time workers with low labor income). A similar subsidy has recently been discussed for Germany (see Bargain et al. 2010). Another form of hours conditions are tax credits for individuals who work at least a specific amount of hours per week, as in place in the United Kingdom. Blundell and Shephard (2012) show that such an hours contingent payment may be optimal as a full-time bonus, which is in line with our Full-Time scenario. ${ }^{4}$ In contrast to the social security subsidies or tax credits analyzed in the aforementioned articles, we analyze direct employment subsidies that are withdrawn only at relatively high levels of labor income. These are very similar to the ones proposed by Keane (1995) who finds that for the United States such hours subsidies are a cost-effective way of improving work incentives for lone parents living on low income. In the reforms Employment and Full-Time analyzed in our paper, people working more than the respective hours threshold receive a net transfer of 1,560 Euro per year.

Our study adds to the literature on revenue neutral basic income systems for several European countries (see, e.g., Colombino et al. 2010; Colombino and Narazani 2013). A closely related study of a revenue neutral flat tax is conducted in Aaberge et al. (2000). For Germany, there are several studies on basic income and flat-tax schemes scenarios (see, e.g. Colombo et al. 2008; Fuest et al. 2008; Straubhaar 2008; Horstschräer et al. 2010), however, none of them considers a tax and transfer schedule that is flat over the whole range of taxable income and does not include a basic allowance. Moreover, most of the scenarios are not revenue neutral. Our study is the first

\footnotetext{
${ }^{3}$ Unemployment Benefit I is insurance based and available to short-term unemployed people (less than 12 to 24 month, depending on age), Unemployment Benefit II is means tested (income and wealth) and available to unemployed people not entitled to Unemployment Benefit I, and social assistance refers to benefits for households that are not in the labor force.

${ }^{4} \mathrm{~A}$ similar concept is the earned income tax credit (EITC) which is not conditional on working hours. See Hotz and Scholz (2003) for a review and Immervoll et al. (2007) for a microsimulation analysis of reform scenarios similar to the EITC.
} 
to analyze a flat tax for Germany that is revenue neutral.

We find that all three reforms increase labor supply in the first decile of the income distribution. The flat tax scenario reduces overall labor supply by $4.9 \%$, the Employment reform reduces labor supply by $1 \%$, while the Full-Time reform has a negligible effect on overall labor supply. With equal welfare weights, aggregate welfare gains are realizable under all three reforms. The stronger the redistributive taste, the higher are the welfare gains of the flat tax reform.

The next section presents the reform scenarios in detail and contrasts them to the current tax and transfer system. Section 3 presents the budget constraints as well as participation tax rates imposed by the reform scenarios. Section 4 describes our empirical approach, Section 5 presents estimated labor supply and welfare effects and Section 6 concludes.

\section{The Reform Scenarios}

The German progressive income tax system is characterized by a basic allowance and two "progressive zones" with increasing marginal tax rates and a constant marginal tax rate in the two "linear zones". For married couple households joint filing is the rule ${ }^{5}$, and the interaction with means tested social transfers complicates the tax-benefit system greatly. Social security receipts derived from previous contributions to the public pension, unemployment and health insurance funds are not directly taxed but may affect the marginal tax rate. The means tested Unemployment Benefit II provides the subsistence level for people unable to work and children. The subsistence level differs by region due to different costs of living, but a typical single household receives about 800 Euro per month of Unemployment Benefit II (Appendix for $§ 28$ Sozialgesetzbuch (SGB) XII and housing costs). Social Assistance or Unemployment Benefit II for the first child in a household is 380 Euro per month (ibid). ${ }^{6}$ For couple households and families with children the subsistence level for each member is adjusted relative to the one of the household head and differs by the number and age of children living in the household. The main components of the current system (Status Quo $2015)^{7}$ and their changes under the alternative reform scenarios are summarized in Table 1.

\footnotetext{
${ }^{5}$ Married couples may choose to be taxed jointly and make use of income splitting. This implies that the income tax of a married couple is calculated by applying the tax function to half of the sum of taxable incomes of the spouses, and the resulting amount is then doubled to determine the tax liability of the couple.

${ }^{6}$ More precisely, the standard rates are 364, 328, 287, 251, 215 Euro for singles, partners, each child of age 15 to 18,7 to 14,0 to 6 , respectively. Moreover, appropriate costs of lodging and heating are covered.

${ }^{7}$ For the simulations we use parameters and data of the most recent year implemented in the STSM (2011).
} 
Table 1: Current System and Changes under Alternative Reform Scenarios.

\begin{tabular}{|c|c|c|c|}
\hline Status Quo (2015) & Employment & Full-Time & Flat Tax \\
\hline \multicolumn{4}{|l|}{ Marginal Tax Rates (MTRs) } \\
\hline Basic allowance of 8,354 Euro & No Change & No Change & - \\
\hline 1st progressive zone: increasing MTR from 0.14 & increasing MTR from 0.21 & No Change & - \\
\hline $\begin{array}{l}\text { 2nd progressive zone: increasing MTR from } 0.24 \\
\text { from } 13,470 \text { Euro }\end{array}$ & $\begin{array}{l}\text { increasing MTR from } 0.245 \\
\text { from } 13,470 \text { Euro }\end{array}$ & No Change & - \\
\hline 1st linear zone: MTR of 0.42 from 52,882 Euro & No Change & No Change & MTR of 0.6885 \\
\hline 2nd linear zone: MTR of 0.45 from 250,731 Euro & No Change & No Change & - \\
\hline \multicolumn{4}{|l|}{ Transfers and Marginal Withdrawal Rates (MWRs) } \\
\hline about 800 Euro/month for first adult & No Change & No Change & Basic income of 800 Euro/month \\
\hline 380 Euro/month for first child & No Change & No Change & 380 Euro/month for children \\
\hline Allowance of 100 Euro/month & - & - & - \\
\hline MWR of 0.8 up to monthly income of 1,000 Euro & $\begin{array}{l}\text { MWR of } 0.6 \text { up to income of } 1,200 \text { Euro } \\
\text { (1,500 Euro with children in household) }\end{array}$ & & MWR of 0.6885 \\
\hline $\begin{array}{l}\text { MWR of } 0.9 \text { up to monthly income of } 1,200 \text { Euro } \\
\text { (1,500 Euro with children in household) }\end{array}$ & & & (All other transfers \\
\hline MWR of 1 afterwards & MWR of 1 afterwards & MWR of 1 & $\begin{array}{l}\text { for people under } 65 \\
\text { are abolished) }\end{array}$ \\
\hline \multicolumn{4}{|l|}{ Employment Subsidy } \\
\hline- & $\begin{array}{l}\text { Subsidy of } 1,560 \text { Euro/year } \\
\text { for people working at least } 10 \mathrm{~h} / \text { week } \\
\text { Withdrawn at rate of } 0.19 \\
\text { from } 28,250 \text { Euro/year }\end{array}$ & $\begin{array}{l}\text { Subsidy of } 1,560 \text { Euro/year } \\
\text { for people working at least } 30 \mathrm{~h} / \text { week } \\
\text { Withdrawn at rate of } 0.19 \\
\text { from } 27,150 \text { Euro/year }\end{array}$ & - \\
\hline \multicolumn{4}{|l|}{ Social Security Contributions (SSC) and Mini-Jobs } \\
\hline $\begin{array}{l}\text { Mini Jobs (up to } 450 \text { Euro/month) } \\
\text { are exempted from income tax and SSC } \\
\text { Midi Jobs (up to } 850 \text { Euro/month) } \\
\text { Marginal SSC of } 0.27 \\
\text { Afterwards marginal SSC of } 0.19\end{array}$ & Mini and Midi Job rules abolished & Mini and Midi Job rules abolished & $\begin{array}{l}\text { Mini and Midi Jobs abolished } \\
\text { SSC are contained in flat tax }\end{array}$ \\
\hline
\end{tabular}

Notes: SSC include unemployment insurance, old age insurance, health insurance and long term care insurance. Marginal SSC are up to specific income levels for different SSC components. For all reform scenarios the employer's contribution remains unchanged. 
The Employment scenario stipulates increases in marginal tax rates by raising the starting marginal tax rate of the progressive zones. The Full-Time reform scenario does not involve changes in the tax schedule. To increase incentives to take up work, the Employment and Full-Time reform scenarios involve tax-free employment subsidies which are withdrawn at a rate of 0.19 when individual labor incomes exceed a specific threshold. The Employment scenario stipulates a subsidy of 130 Euro a month, which amounts to about $12.5 \%$ of monthly per capita net income, for people who work at least 10 hours per week. It is withdrawn at a rate of 0.19 starting at individual labor incomes of 28,250 per year. As a further work incentive for people with low incomes, marginal transfer withdrawal rates are reduced from virtually $100 \%$ to $60 \%$ up to monthly incomes of 1,200 Euro (1,500 Euro for people with children). As the scenario comprises subsidization even of jobs with few weekly working hours and thereby aims to increase employment in general, it is called Employment in the following.

The Full-Time reform scenario involves a subsidy of the same amount for full-time jobs only (at least 30 hours per week). It is withdrawn starting at individual labor incomes of 27,150 Euro. In order to further improve incentives to work full-time, transfers are withdrawn at a rate of $100 \%$, making part-time employment for transfer recipients less attractive. Under the status quo, transfer recipients can earn 100 Euro per month without any withdrawal, but from this point onwards, marginal withdrawal rates are high. The Employment reform scenario stipulates a reduction of marginal withdrawal rates to $60 \%$ up to monthly incomes of 1,200 Euro (1,500 Euro for households with children). The Full-Time reform scenario imposes marginal withdrawal rates of $100 \%$. The employment subsidies are financed by abolishing tax and social security exemptions for marginal employment ("Mini Jobs" and "Midi Jobs"). This is done because these exemptions create strong disincentives for secondary earners to work more than the marginal employment threshold (450 Euro). This disincentive is illustrated in the next section (Figure 3a). The employment subsidies of the reform scenarios Employment and Full-Time are alternative ways to subsidize employment of low wage workers.

In the Flat Tax reform the basic income is set at a similar amount as under the current subsistence level guaranteed through Unemployment Benefit II and Social Assistance. This amounts to 800 Euro per month for adults and 380 Euro for each child below the age of 18 years living in the household. ${ }^{8}$ In contrast to the current transfer system, the basic income level does not differen-

\footnotetext{
${ }^{8}$ Note that in all scenarios except for Flat Tax, there is an in-work tax credit for families ("Kinderzuschlag"), granted to parents whose income is sufficient to sustain for themselves but not for the expenses for their children.
} 
tiate by the number and age of children and the transfer is not means tested. The rate of the flat tax, which includes social security contributions, necessary to finance this basic income scheme is about $69 \%$, and the basic income is withdrawn at the same rate. In all three reform scenarios the pension system remains unchanged, therefore transfers change only for people up to 65 years of age.

\section{Incentives and Budget Constraints}

Figure 1a shows the overall marginal tax rate for a single household without children earning an hourly wage of 20 Euro in the status quo and for each of our reform scenarios, Full-Time, Employment, and Flat Tax. We abstract from rounding rules in this presentation and use a resolution of 1 Euro in all two-dimensional graphs. Overall marginal tax rates are defined on the basis of personal income taxes, social security contributions and transfer payments. We censor marginal tax rates at -0.2 and 1.2 to increase readability of the graphs. In the status quo, marginal tax rates are zero at very low monthly household gross labor income levels/working hours because of allowances and deductions regarding transfers. Then, the overall marginal tax rate increases to a level of $80 \%$ which is the transfer withdrawal rate. When labor income subject to transfer withdrawals exceeds 1,000 Euro, the marginal withdrawal rate is increased to $90 \%$. When it exceeds 1,200 Euro, the MTR is $100 \%$. At about 18 hours, the exemplary household does not receive any transfers anymore and pays social security and personal income taxes, which together amount to about $42 \%$.

The Full-Time reform starts with a marginal social security contribution of $20 \%$ as the social security exemption (Mini Jobs) is abolished in this scenario. When labor income exceeds lump sum allowances for expenses, the overall marginal tax rate, including the transfer withdrawal, increases to $100 \%$. When transfers are completely withdrawn, in our example at about 12 working hours, the household pays social security contributions and personal income taxes similar to the status quo. At 30 hours the household receives the employment subsidy, a discontinuity which is represented by a spike. Right from the beginning and up to about 35 hours, the subsidy is withdrawn at a marginal rate of $19 \%$. The overall marginal tax rate under this reform scenario therefore exceeds the one under the status quo from 0 to 12 and from 30 to 34 hours and attains the same level as under the status quo for longer working hours. Although social security exemptions for low wage earners are also abolished in the Employment scenario, due to the smaller marginal transfer withdrawal rate of $60 \%$ and the lower threshold of working hours, for this exemplary household 
the overall marginal tax rate up to 14 working hours is considerably lower under this scenario than under the Full-Time reform scenario. Due to the absence of the means test, the overall marginal tax rate under the Flat Tax reform scenario is below that under the status quo for levels of household labor income under about 1.500 Euro per month, and exceeds that rate for incomes above that level. Marginal tax rates under the Flat Tax reform scenario are also markedly lower than under the Full-Time scenario for relatively low earnings and small working hours, whereas marginal tax rates under the Employment scenario are high relative to the Flat Tax scenario between 14 and 24 working hours for this exemplary household.

Figure 2a shows the budget constraints for the same exemplary household under the status quo and the three reform scenarios. Clearly, in the Full-Time scenario the household is worse off at low incomes. Once transfers are completely withdrawn, net income is identical under FullTime and the status quo. At 30 hours, when the employment subsidy is received the household's net income exceeds that under the status quo until the subsidy is fully withdrawn at about 35 hours. In contrast, under the Employment scenario, due to the employment subsidy already paid at 10 working hours the household's net income is initially substantially increased compared to the status quo, but subsequently increases little with higher earnings when the employment subsidy is being withdrawn. Due to the higher marginal tax rates on higher incomes required to balance the budget under this scenario, the exemplary household becomes worse off than under the status quo at earnings of about 2,500 Euro per month. Under the Flat Tax for labor incomes between about 500 and 2,600 Euro the household's net income would increase, but would decrease relative to the status quo for higher earnings levels.

Figure $1 b$ illustrates how the marginal tax rates change for a married couple with two children. We vary the level of labor income of the primary earner, while holding the labor income of the secondary earner constant at 20,000 Euro per year. Under the current transfer system, the subsistence level of a couple with two children exceeds that amount, and the exemplary household would therefore be eligible to Unemployment Benefit II if the primary worker did not work. Marginal tax rates for couples follow a similar pattern as for single households in the status quo and in all reform alternatives. In the Full-Time scenario, the household receives transfers only for a relatively small income range of the primary earner. Note the striking difference between scenarios in Figure $2 \mathrm{~b}$ that shows that for all income levels of the primary earner, the Flat Tax leads to higher net income than all other reform scenarios and the status quo. This is due to the fact that the basic income does not depend on household size in the Flat Tax scenario.

In the appendix, Figures 6 and 8 present the overall marginal tax rates, Figures 7 and 9 the 


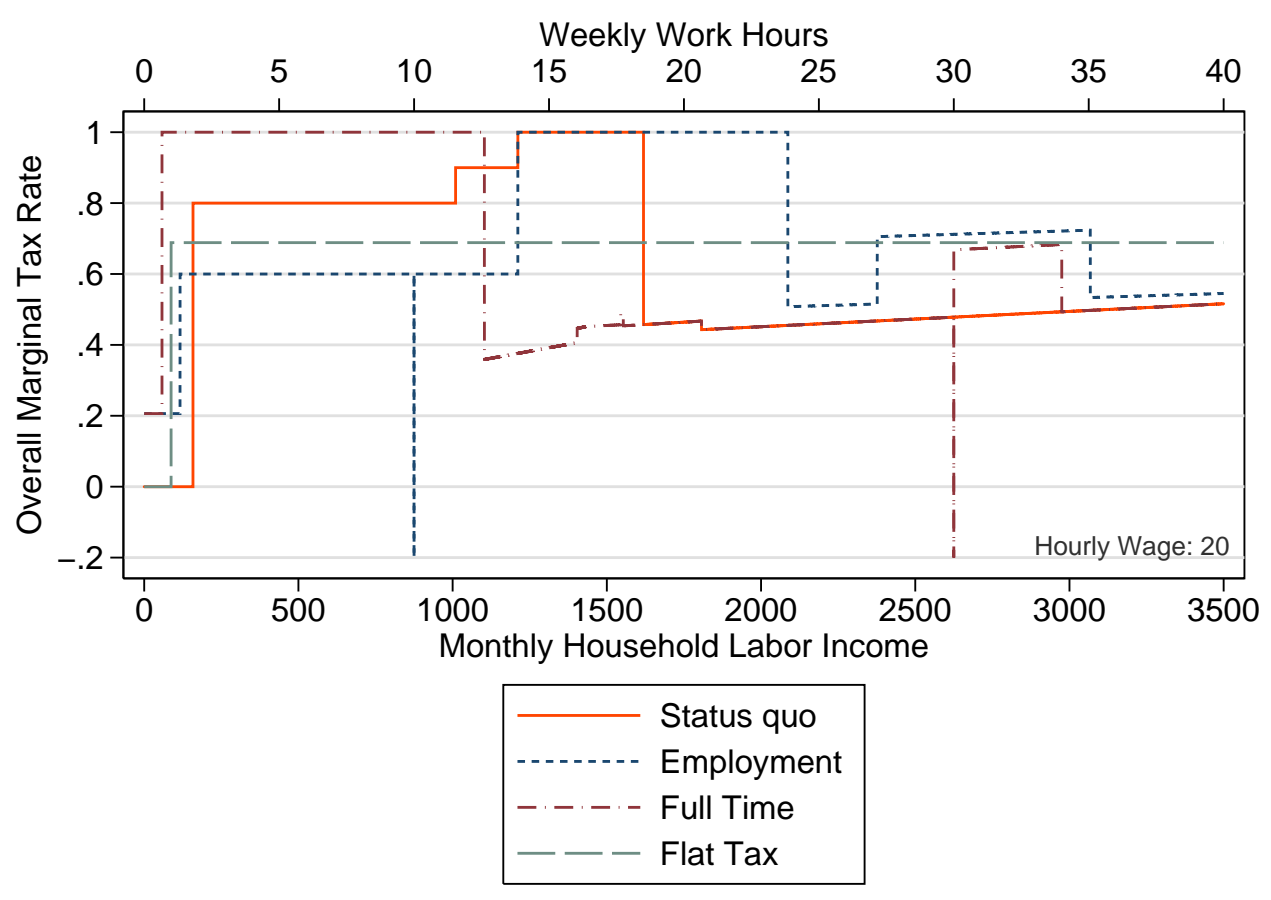

(a) Single Person without Children

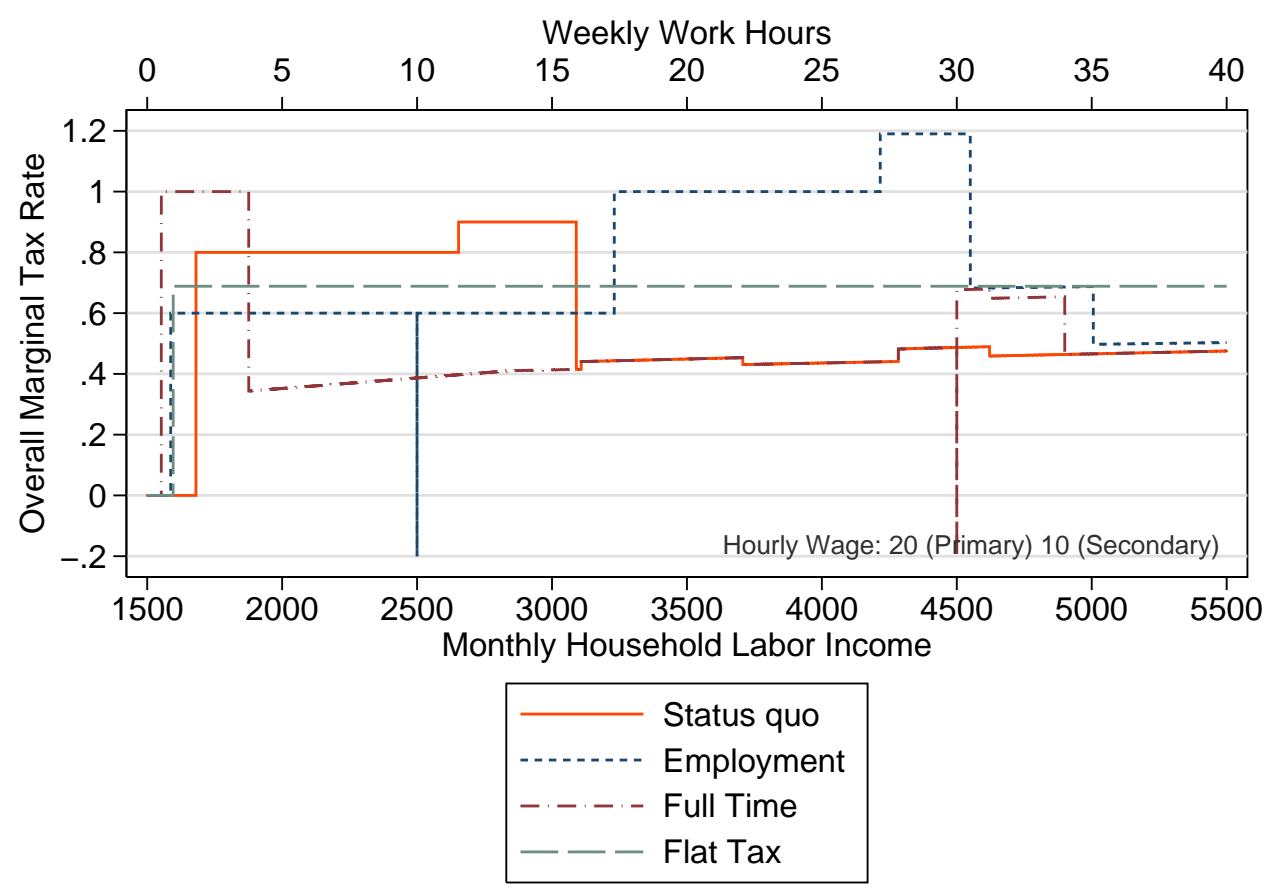

(b) Married Couple with Two Children

Figure 1: Marginal Tax Rates by Monthly Household Gross Labor Income and Weekly Working Hours in Germany, 2011. Source: Own calculations based on a modified version of the STSM. 


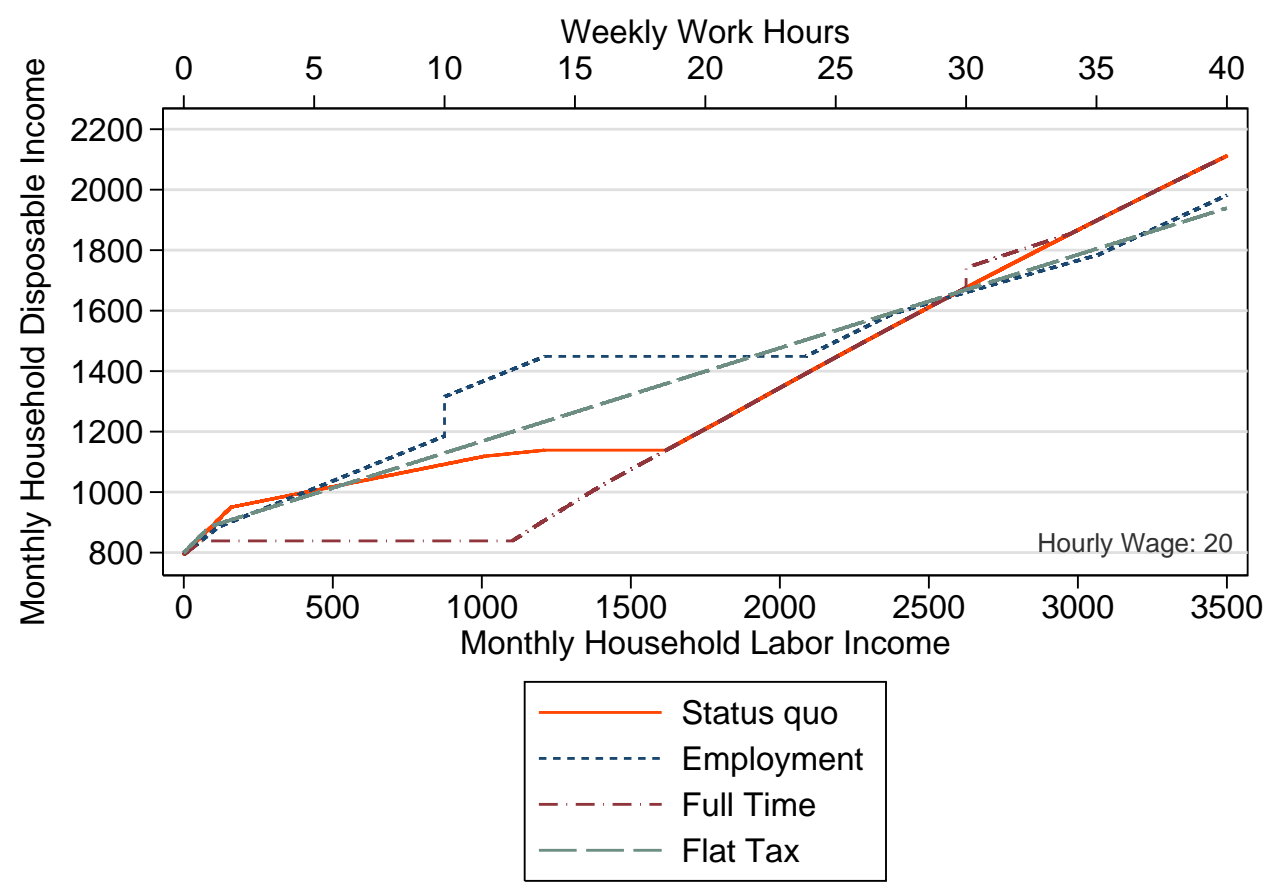

(a) Single Person without Children

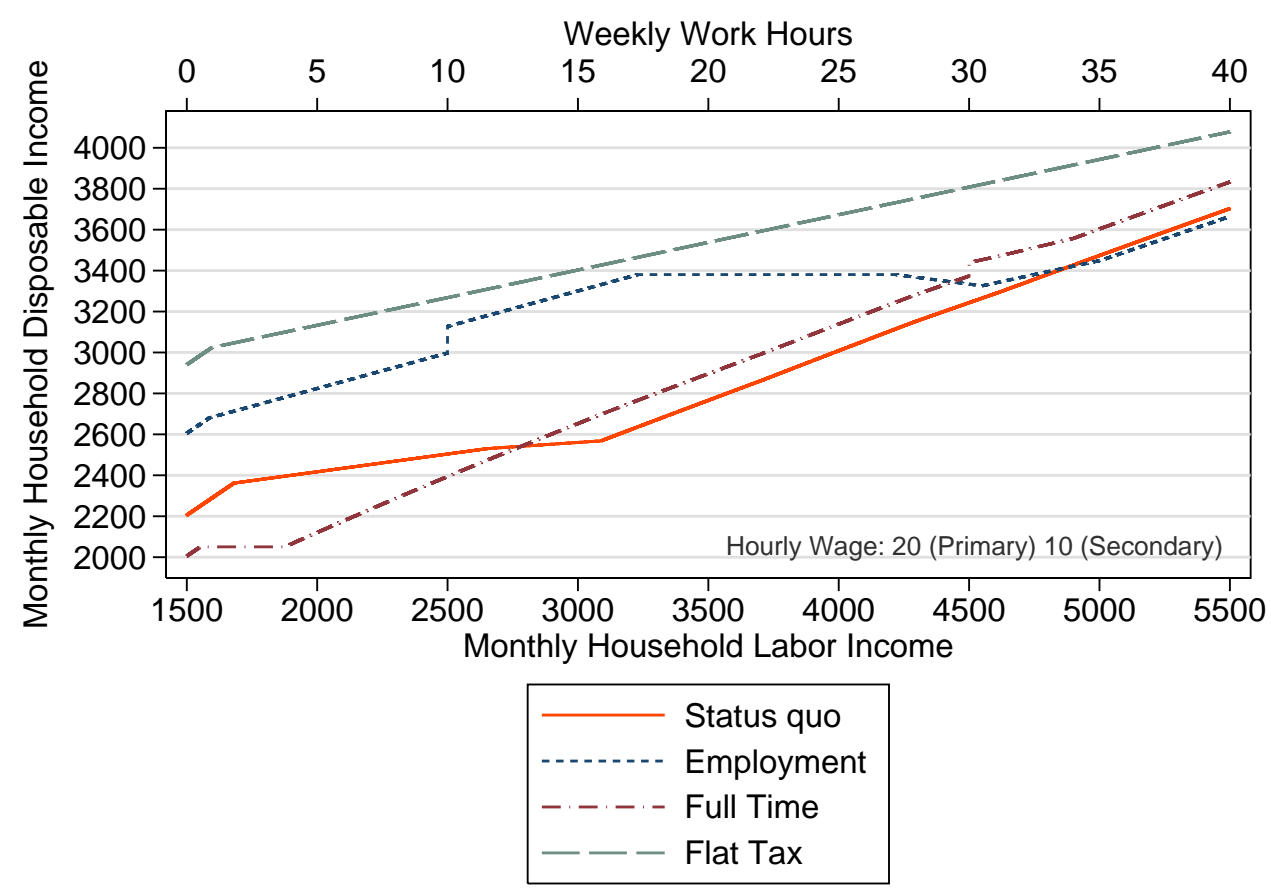

(b) Married Couple with Two Children

Figure 2: Budget Constraints by Monthly Household Gross Labor Income and Weekly Working Hours in Germany, 2011. Source: Own calculations based on a modified version of the STSM. 
budget constraints for households with different characteristics. In particular, we vary the number of children and the hourly wage. Figure 10 shows both marginal tax rates and budget constraints the two households presented in Figure 1 and 2 would have if all members earned 10 Euro per hour each. These figures show that with more children the marginal tax rate is very high, even with relatively high labor income. This brings about strong disincentives for parents to work.

In the case of couple households it is instructive to consider the entire choice set of these households. For the status quo and the three alternative reform scenarios, Figure 3 depicts the overall marginal tax rates of the primary earner for various labor income levels of the primary and the secondary earner for a couple household with two children where both spouses earn 10 Euro per hour. ${ }^{9}$ At three vertices of the cube, three numbers are reported. The first number shows labor income of the secondary earner, the second the overall marginal tax rate, and the third labor income of the primary earner. Labor income of the primary earner increases from left to right, and that of the secondary earner increases to the north-east holding primary earner's income constant. The vertical axis represents the overall marginal tax rate. All three-dimensional graphs abstract from rounding rules and are constructed in such a way that the horizontal distance between two points is 133 Euro monthly labor income. We indicate higher points in red (appearing as darker shading in monochrome) and lower points with a light teal (lighter shading). Moreover, we use different markers to distinguish higher points from lower ones in the order circles (lowest), diamonds, squares, triangles (highest). As with the two-dimensional graphs, we cap marginal tax rates at -0.2 and 1.2 .

Figure 3a shows that, due to joint taxation of couples, the MTR increases with raising income of the other spouse as soon as monthly labor income of the primary worker exceeds 400 Euro, the amount exempted from taxation and social security contributions in $2011 .^{10}$ When monthly labor income exceeds 400 Euro, the entire labor income becomes taxable. Thus, overall MTR are quite high forming a crest at 400 Euro labor income of the primary earner. This adverse incentive is abolished in all reform scenarios that we analyze. The figure also shows the effect of the withdrawal of Unemployment Benefit II by step-wise increases of the MTR with increasing labor income of the secondary worker at low levels of the primary earner's labor income. Furthermore, the effect of joint taxation of couples on MTR is clearly visible. The marginal tax rate of the pri-

\footnotetext{
${ }^{9}$ Figure 3 and 4 are produced using the user written Stata ado graph3D, see Jessen and Rostam-Afschar (2014).

${ }^{10}$ Income form marginal employment that exceeds 100 Euro per month is, however, not exempted from transfer withdrawal.
} 
mary earner depends on the labor income of the secondary earner which is visible for diagonals through the cube that correspond to points where the sum of labor income of both earners is the same. On these diagonals, the MTRs of the primary earner are constant under joint taxation but not under individual taxation. When comparing Figure $3 \mathrm{a}$ to Figure 10b, which represents the same household, note that the latter denotes monthly household income on the horizontal axis.

Figure $3 b$ presents work incentives of the Full-Time scenario. Compared to the status quo, the MTR crest vanishes because tax exemptions for marginal employment are abolished under this alternative. Transfer withdrawal rates are higher and begin at lower income levels (more to the left). At an income of the primary earner of about 1,200 Euro (30 h), the employment subsidy causes a negative spike in the marginal tax rate. This lump sum payment is withdrawn at higher earnings levels of the primary earner, thereby reducing incentives to increase working hours.

The Employment scenario, instead, improves incentives to work in two ways. First, marginal transfer withdrawal rates for labor incomes below 1,500 Euro are reduced substantially. The effect of the employment subsidy on the MRT is again depicted as a downward spike at 400 Euro for the primary earner. Second, transfers are withdrawn at a rate of $100 \%$ above this threshold and, on top of this, the employment subsidy is withdrawn from labor incomes of about 2,200 Euro on. This leads to higher marginal withdrawal rates compared to the status quo in this region. After all transfers are withdrawn, the marginal tax rates are similar to those of the status quo but slightly higher. In contrast to the status quo and the reform scenarios that involve specific employment subsidies, except for very low levels of primary earner's labor income the Flat Tax scenario provides the same incentives for all levels of incomes irrespective of how earnings are distributed between the two spouses living in the same household.

To show how different combinations of primary and secondary labor incomes affect disposable income of the household, Figure 4 presents three-dimensional budget graphs for the same household as above that can be similarly interpreted as the graphs in Figure 3. The only difference is that the vertical axis represents monthly disposable income. In Figure $4 \mathrm{a}$ a bulge observable at lower household incomes represents transfer payments in the status quo. It is highest at the diagonal starting from zero to maximum household income. This is because transfers are paid allowing for additional earnings. At higher incomes when the household is not eligible for transfers anymore, the budget constraint becomes almost a plane (due to joint taxation). At low incomes of the primary and the secondary earner, respectively, trenches caused by the tax exemption for marginal employment are clearly visible.

Figure $4 \mathrm{~b}$ shows a flat area at low labor incomes in the Full-Time alternative due to marginal 


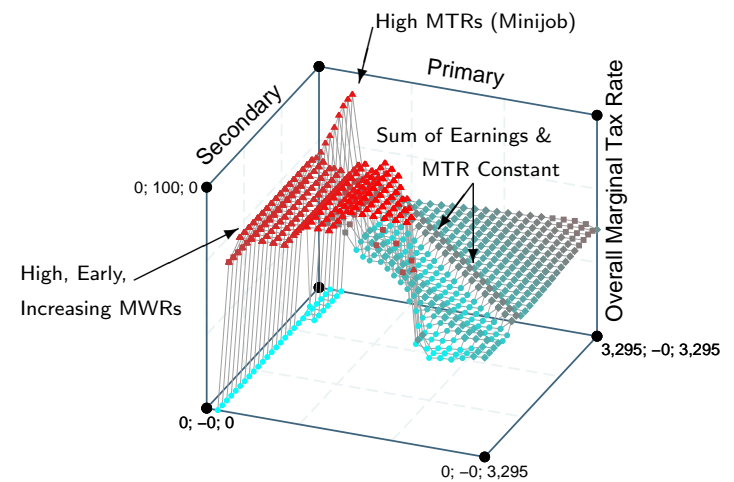

(a) Status Quo

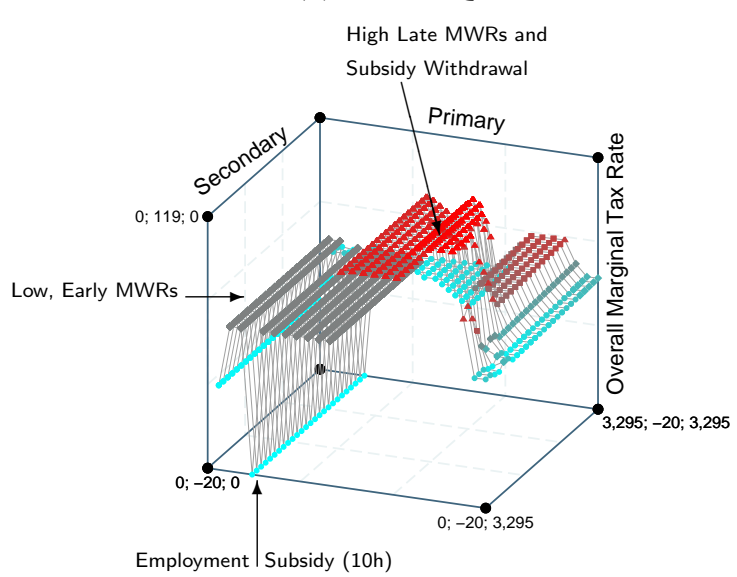

(c) Employment

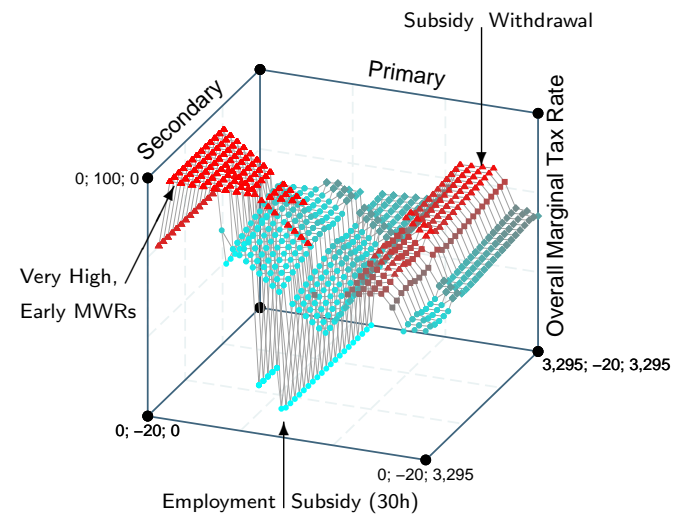

(b) full-time

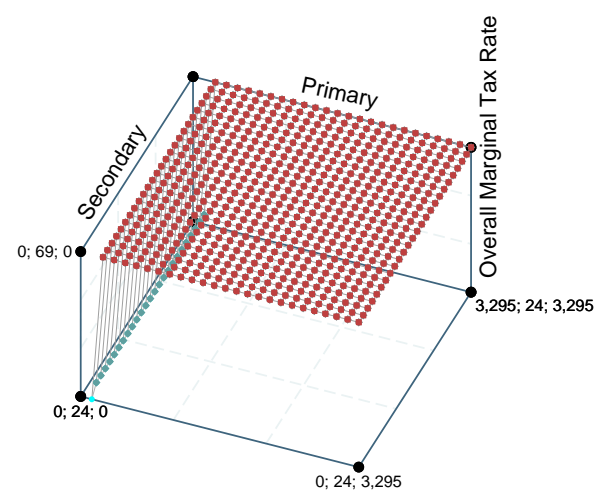

(d) Flat Tax

Figure 3: Marginal Tax Rate by Monthly Gross Labor Income of Both Spouses in Germany, 2011. Source: Own calculations based on a modified version of the STSM. 


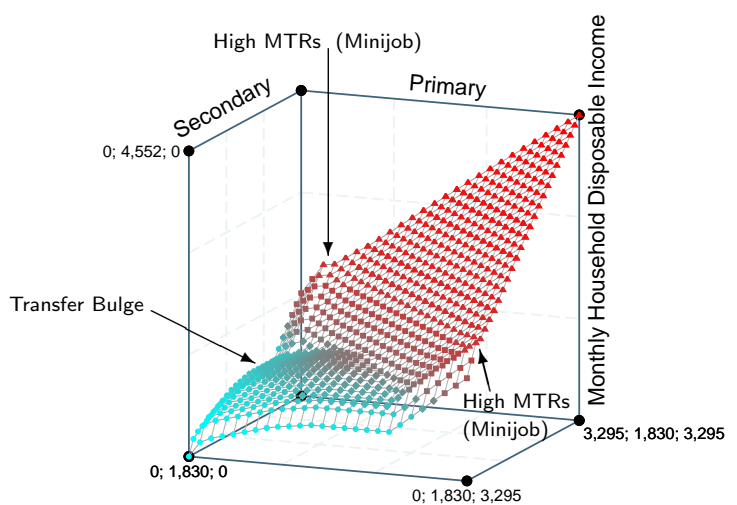

(a) Status Quo

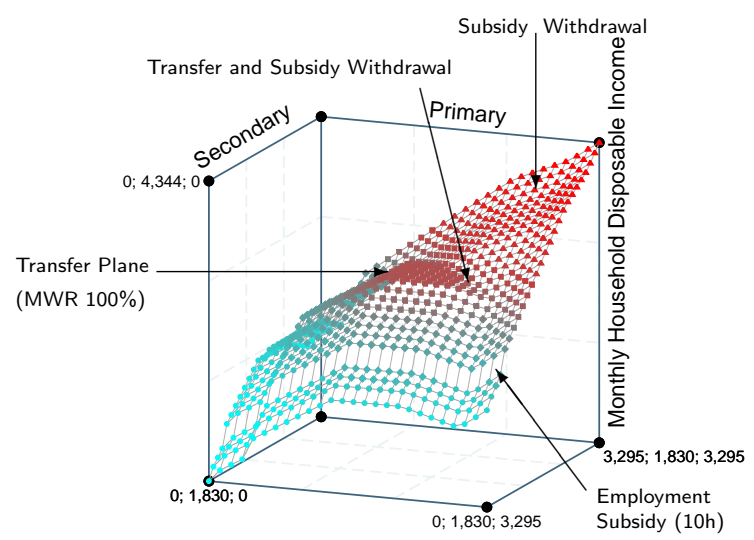

(c) Employment

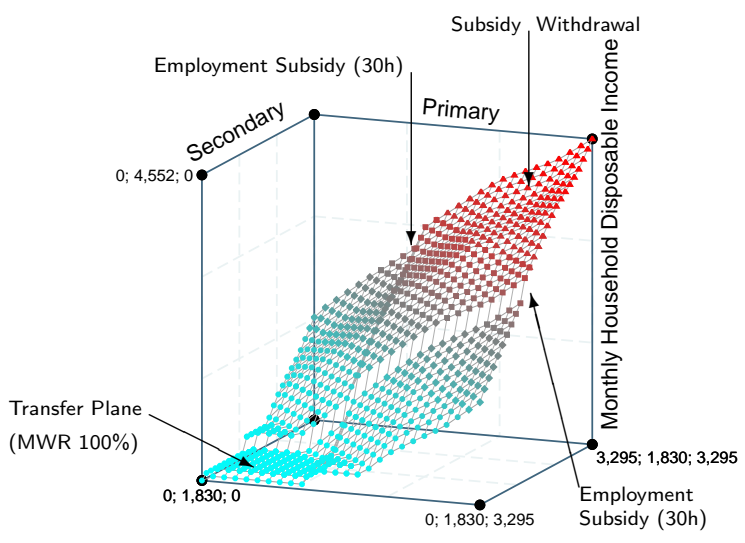

(b) full-time

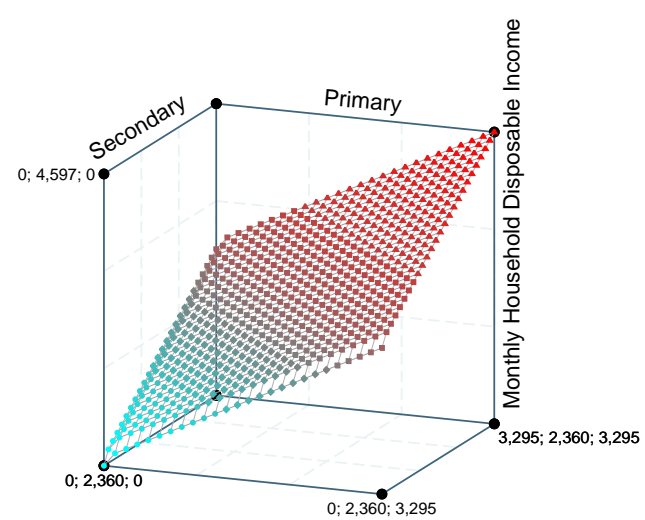

(d) Flat Tax

Figure 4: Budget Constraints by Monthly Gross Labor Income of Both Spouses in Germany, 2011. Source: Own calculations based on a modified version of the STSM. 
withdrawal rates of $100 \%$. As soon as one of the spouses earns more than about 1,200 Euro the employment subsidy is received. This causes an elevation in the budget surface. The withdrawal of the employment subsidy makes the surface slightly flatter at higher levels compared to the status quo. For each level of household labor income, in this reform the allocation of working hours between partners makes a difference which is not the case in the status quo. The reason is that, in contrast to household-based taxes, the employment subsidy is granted individually. Points where both partners work full-time result in higher net income as shown in the figure.

In Figure 4c, the employment subsidy of the Employment reform is visible starting from about 400 Euro of labor incomes as an area bulging incomes upwards. Recall that because from 1,500 Euro labor income on transfers are withdrawn at a rate of $100 \%$, net income is unchanged with increasing labor income. Net income even decreases for labor incomes over 2,200 Euros when the household still receives unemployment benefits. This is because the transfer withdrawal rate and the withdrawal of the subsidy add up to $119 \%$.

Flat Tax leads to a flat budget surface depicted in Figure 4d. As in the status quo, different labor income combinations that imply a given level of household labor income result in the same amount of household net income.

To make the analyzed reforms comparable to the literature (Bartels and Pestel 2015; Immervoll et al. 2007), we show "participation tax rates" (PTR) in Table 2 for interesting discrete decisions of exemplary households for all reform scenarios. This measure is calculated as

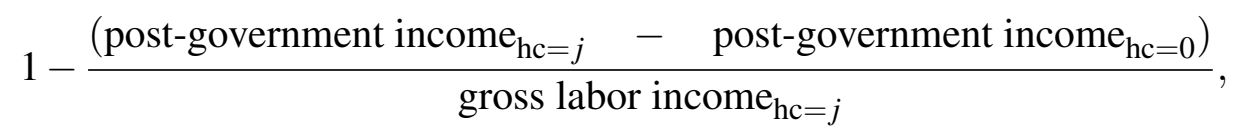

where $j$ indicates the hours categories (hc) where at least one household member works part-time $(20 \mathrm{~h})$ or full-time $(40 \mathrm{~h}) . h c=0$ denotes that no household member works. The higher the participation tax rates, the more the tax and transfer system reduces the monetary incentives to work. The exemplary household holds no wealth and does not earn non-labor income and is thus eligible to Unemployment Benefit II (see Section 2). 
Table 2: Participation Tax Rates in Percent.

\begin{tabular}{lcccc}
\hline & Employment & Full-Time & Flat Tax & Status Quo \\
\hline Couples (Primary Earner Hourly Wage: 20 Euro, Secondary 10 Euro) & & \\
full-time (40h), 0 children & 59 & 56 & 67 & 58 \\
full-time (40h), 1 child & 61 & 58 & 67 & 60 \\
full-time (40h), 2 Children & 64 & 61 & 67 & 63 \\
part-time (20h), 0 children & 55 & 71 & 64 & 71 \\
part-time (20h), 1 child & 50 & 76 & 64 & 74 \\
part-time (20h),2 Children & 50 & 82 & 64 & 74 \\
full-time (40h) -Zero Hours(0h), 0 children & 68 & 65 & 67 & 65 \\
full-time-Zero Hours, 1 child & 72 & 68 & 67 & 68 \\
full-time-Zero Hours,2 Children & 76 & 73 & 67 & 73 \\
full-time (40h) -part-time (20h), 0 children & 61 & 60 & 66 & 60 \\
full-time-part-time, 1 child & 64 & 63 & 66 & 63 \\
full-time-part-time,2 Children & 67 & 67 & 66 & 67 \\
& & & & \\
Singles (Hourly Wage: 20 Euro) & 66 & 62 & 67 & 62 \\
full-time (40h), 0 children & 69 & 65 & 65 & 65 \\
full-time, 1 child & 72 & 69 & 65 & 69 \\
full-time,2 Children & 62 & 76 & 65 & 76 \\
part-time (20h), 0 children & 55 & 83 & 61 & 78 \\
part-time, 1 child & 55 & 90 & 61 & 78 \\
part-time,2 Children &
\end{tabular}

Source: Source: Own calculations based on a modified version of the STSM.

Couples with a primary earner with an hourly wage of 20 Euro and a secondary earner with an hourly wage of 10 Euro face the strongest incentive to work both full-time in the Full-Time scenario (PTR of 56 percent for a couple without children). Compared to the status quo (PTR of 58 percent) and Employment (PTR of 59 percent) these incentives are quite similar, while the Flat Tax offers weaker incentives (PTR of 67 percent) to work full-time. Employment dominates all other alternatives regarding incentives to work part-time (PTR of 50 percent for a couple with one child), while Flat Tax offers the second best incentives and Full-Time is similar to the status quo. The picture is similar for a single with 20 Euro hourly wage. However, the Flat Tax offers the best incentives to work full-time for singles with children.

Incentives for all employment choices worsen with an increasing number of children for all scenarios except for the Flat Tax. Also in the Employment scenario, incentives to take up part-time work do not deteriorate with the number of children. If the household has a child compared to the same household without children, in the status quo, the PTR increases from 65 to 68 percent e.g. 
if one partner works full-time and the other zero hours. With two children, the PTR increases to 73 percent.

For couples and singles with hourly wages of 10 Euro, the Employment reform offers the lowest participation tax rates (not reported) for all employment states relative to unemployment, save for full-time working couples with no children. This is due to the fact that the decrease in transfer withdrawal rates is especially relevant for low wage households.

\section{A Structural Labor Supply Model}

We estimate the effect of the three hypothetical reforms on welfare, labor supply and government revenues using the microsimulation model STSM, see Steiner et al. (2012). In addition to the income tax formula and transfers it accounts for deductions, allowances, social security payments and child benefits as well as the interactions of the different components of the tax and transfer system on the household level. The underlying database is the Socioeconomic Panel (SOEP), an annual representative survey of German households with about 20,000 observations per year, see Wagner et al. (2007). In this study we use the wave 29, which contains retrospective information for the year 2011. The specification of the structural household labor supply model embedded in STSM follows van Soest (1995); Aaberge et al. (1995); Aaberge and Colombino (2014). Households are assumed to jointly maximize utility, which depends on hours worked and consumption. Given their hourly wage, agents make a discrete choice of weekly working hours. The discretization of working hours into $j$ alternatives allows for the precise calculation of net incomes associated with labor supply decisions using the STSM and-in contrast to continuous labor supply models - does not impose any restrictions on the form of the budget set, such as convexity. Additionally, this approach accounts for joint labor supply decisions of couples in a consistent way. We discretize female weekly working hours into $0,10,20,30,38$ and 45 and male weekly working hours into $0,10,20,30,38$, and 48 , which results in six choice alternatives for single households and 36 alternatives for couples. Gross labor income is given by the product of working hours and the hourly wage. Potential hourly wages of the unemployed as well as hourly wages of employed with item non-response are predicted using a selectivity-corrected wage regression, where selection is accounted for by the two-step Heckman (1979) approach with binary variables for young children of four age groups, marital status, non-labor income, and indicators for health as exclusion restriction. Let $L f$ denote leisure of the female partner, $L m$ leisure of the male partner, $C$ 
consumption, and $\varepsilon$ a random disturbance. Then the utility of household $i$ of choice alternative $j$ is given by

$$
V_{i j}=U\left(L f_{i j}, L m_{i j}, C_{i j}\right)+\varepsilon_{i j}
$$

We use the translog specification of the deterministic part of individual utility and allow for interactions of the components of the utility fuction, i.e.:

$$
\begin{array}{r}
U_{i j}=\beta_{1} \ln \left(C_{i j}\right)+\beta_{2} \ln \left(C_{i j}\right)^{2}+\beta_{3} \ln \left(L f_{i j}\right)+\beta_{4} \ln \left(L f_{i j}\right)^{2}+\beta_{5} \ln \left(L m_{i j}\right) \\
+\beta_{6} \ln \left(L m_{i j}\right)^{2}+\beta_{7} \ln \left(C_{i j}\right) \ln \left(L f_{i j}\right)+\beta_{8} \ln \left(C_{i j}\right) \ln \left(L m_{i j}\right)+\beta_{9} \ln \left(L f_{i j}\right) \ln \left(L m_{i j}\right) .
\end{array}
$$

Heterogeneity between households is incorporated through taste shifters—observed household characteristics that affect some of the coefficients of the utility function:

$$
\begin{gathered}
\beta_{1}=\alpha_{0}^{C}+X_{1}^{\prime} \alpha_{1}^{C}, \\
\beta_{3}=\alpha_{0}^{L f}+X_{2}^{\prime} \alpha_{1}^{L f}, \\
\beta_{5}=\alpha_{0}^{L m}+X_{3}^{\prime} \alpha_{1}^{L m} .
\end{gathered}
$$

$X_{1}, X_{2}$ and $X_{3}$ contain individual and household characteristics like age, disability indicators, whether the observed person is German citizen, and number and age of children (see Table 8 for the exact specification of the utility function)

If the error terms $\varepsilon_{i j}$ are assumed to be independently and identically distributed across hour categories and households according to the Extreme-Value type I (EVI) distribution, the probability that alternative $k$ is chosen by household $i$ is given by a conditional logit model (McFadden 1974):

$$
P_{i k}=\operatorname{Pr}\left(V_{i k}>V_{i j}, \forall j=1 \ldots J\right)=\frac{\exp \left(U_{i k}\right)}{\sum_{j=1}^{J} \exp \left(U_{i k}\right)}, k \in J .
$$

Alternative $k$ is chosen if it implies a higher utility than any other alternative. Estimation results for the labor supply model are reported in Table 8. We distinguish between couples with flexible labor supply of both spouses, those with inflexible labor supply of one of the spouses, single men, and single women, where labor supply is assumed to be inflexible for civil servants, selfemployed, pensioners, people on parental leave, soldiers, apprentices, and disabled people who work in sheltered workshops.

Changes in net income associated with specific hours points leads to changes in the choice probabilities given by equation 3. These allow for the calculation of aggregate labor supply effects of the hypothetical reforms. We simulate these effects by the calibration method, i.e., we 
add random error terms from the (EVI) distribution to the estimated utility levels of each choice alternative in the baseline (status quo) simulation until the utility maximizing choice matches the observed labor supply at the individual level. This set of choice specific individual errors is then used in the simulation of labor supply reactions to the reforms (see Creedy and Kalb 2005). ${ }^{11}$

\section{Simulation Results}

\subsection{Effects on Government Revenue}

The three reform scenarios have been calibrated to be close to budget neutral after labor supply reactions. Table 3 shows the changes in government revenues before and after labor supply reactions. In the absence of any labor supply responses the Employment and especially the Flat Tax reforms would result in a substantial increase in government revenues, whereas they would be reduced by about 462 million Euro per year in case of the Full-Time reform. Accounting for labor supply responses renders all three reform scenarios virtually budgetary neutral due to the decrease in employment elicited by the Employment and Flat Tax reforms and a small overall increase in total working hours in case of Full-Time reform, as described below.

Table 3: Changes in Government Revenue in Million Euro

\begin{tabular}{lrrr}
\hline Labor Supply Responses & Employment & Full Time & Flat Tax \\
\hline Before & 3,302 & -462 & 26,187 \\
After & 25 & 16 & 164 \\
\hline
\end{tabular}

Source: Own calculations based on the SOEP v291 (2012) and a modified version of the STSM.

\footnotetext{
${ }^{11}$ We only simulate labor supply responses for households with flexible labor supply and positive first derivatives. The fraction of households with positive derivatives is reported at the bottom of Table 8 .
} 


\subsection{Labor Supply Effects}

Table 4 shows the estimated percentage changes in working hours. The last line of the table shows that both the Employment and Flat Tax scenarios would reduce total labor supply, while the total effect of the Full-Time reform would be negligible. The Employment reform would reduce supplied hours by $1 \%$, the increase induced by the Full-Time reform would be virtually zero, while the Flat Tax reform would reduce supplied hours substantially by $4.9 \%$. For the Employment and Flat Tax reforms, female labor supply reacts more strongly than male labor supply, which is a typical result in labor economics.

All three reforms are designed to improve work incentives for low income households and indeed all three reforms would increase labor supply in the decile with the lowest net equivalence income under the status quo. While the Employment and Full-Time reforms would increase labor supply in the first decile by $0.3 \%$ and $0.9 \%$ respectively, the Flat Tax reform would lead to the strongest increase of $1.4 \%$ in this decile. For all reforms, the positive changes in labor supply would be almost entirely due to men increasing their labor supply in the first decile. For all other deciles, the labor supply effects of the Employment and Flat Tax reforms are negative due to increased marginal tax rates and in case of the Flat Tax the increased transfer income for larger households. The Full-Time reform, which leaves marginal tax rates unchanged has modest effects in the upper nine deciles ranging from $-0.4 \%$ to $0.2 \%$. The lower part of Table 4 shows labor supply reactions by household types-divided into singles and couples with zero, one or more than two children. Overall, the Employment and Flat Tax reforms lead to negative total labor supply changes for all of these household types. The Full-Time reform reduces labor supply for some types of single households and increases labor supply for all types of couple households.

Table 5 shows simulated effects of the reform scenarios on the participation rate by income deciles and households types in percentage points. The effects are in line with the responses for working hours: The Flat Tax has a relatively strong negative effect (-3.3 percentage points), while the negative effects of the Employment reform (-0.3 percentage points) and of the Full-Time reform (-0.2 percentage points) are negligible. The Employment reform succeeds in increasing the participation rate for the two lowest income deciles only, while the effect is positive only in the lowest decile for the Flat Tax and zero or negative in all other deciles. For the Full-Time reform, both positive and negative effects can be found over the income distribution. 
Table 4: Simulated Labor Supply Effects of the Reform Scenarios by Household Types, Over the Income Distribution, and on Aggregate.

\begin{tabular}{|c|c|c|c|c|c|c|c|c|c|}
\hline & \multicolumn{3}{|c|}{ Employment } & \multicolumn{3}{|c|}{ Full-Time } & \multicolumn{3}{|c|}{ Flat Tax } \\
\hline & Women & Men & Total & Women & Men & Total & Women & Men & Total \\
\hline \multicolumn{10}{|c|}{ Changes in Hours Worked (in Percent) } \\
\hline \multicolumn{10}{|c|}{ Deciles of Net Equivalence Income } \\
\hline $1 \mathrm{st}$ & -0.0 & 0.8 & 0.3 & -0.7 & 3.8 & 0.9 & -0.1 & 4.1 & 1.4 \\
\hline 2nd & -0.4 & -0.2 & -0.3 & -0.1 & 0.0 & -0.0 & -2.5 & -0.1 & -1.5 \\
\hline $3 \mathrm{rd}$ & -1.1 & -0.7 & -0.9 & -0.8 & 0.1 & -0.4 & -7.2 & -0.7 & -4.1 \\
\hline 4 th & -3.2 & -0.1 & -1.7 & 0.1 & 0.0 & 0.1 & -3.2 & -0.9 & -2.0 \\
\hline 5 th & -1.7 & -0.2 & -0.9 & -0.2 & 0.1 & -0.0 & -7.2 & -2.3 & -4.7 \\
\hline 6th & -4.8 & -0.2 & -2.4 & -0.2 & 0.0 & -0.1 & -9.2 & -4.0 & -6.5 \\
\hline 7th & -2.3 & -0.9 & -1.6 & 0.5 & -0.1 & 0.2 & -10.0 & -1.6 & -5.6 \\
\hline 8th & -0.7 & -0.6 & -0.7 & 0.0 & 0.0 & 0.0 & -13.4 & -3.0 & -8.1 \\
\hline 9th & -0.6 & -0.1 & -0.3 & -0.1 & -0.1 & -0.1 & -9.1 & -2.6 & -5.4 \\
\hline 10th & -1.7 & -0.2 & -0.8 & -0.0 & -0.0 & -0.0 & -12.0 & -5.1 & -8.0 \\
\hline \multicolumn{10}{|l|}{ By Household Type } \\
\hline Couples, 0 Children & -1.2 & -0.4 & -0.8 & -0.1 & 0.2 & 0.1 & -7.2 & -1.4 & -4.0 \\
\hline Couples, 1 Child & -1.0 & -0.4 & -0.7 & -0.1 & 0.3 & 0.1 & -6.7 & -1.5 & -3.8 \\
\hline Couples, $2+$ Children & -1.0 & -0.4 & -0.7 & -0.2 & 0.3 & 0.1 & -6.6 & -1.6 & -3.8 \\
\hline Singles, 0 Children & -2.2 & 0.0 & -1.2 & -0.2 & 0.0 & -0.1 & -9.2 & -4.6 & -7.1 \\
\hline Singles, 1 Child & -4.1 & 0.0 & -3.7 & 0.2 & 0.0 & 0.1 & -8.2 & -14.3 & -8.8 \\
\hline Singles, $2+$ Children & -3.0 & 0.0 & -2.6 & -0.9 & 0.0 & -0.7 & -4.4 & -0.7 & -3.8 \\
\hline All Households & -1.7 & -0.3 & -1.0 & -0.1 & 0.2 & 0.0 & -7.7 & -2.2 & -4.9 \\
\hline
\end{tabular}

Source: Own calculations based on the SOEP v291 (2012) and a modified version of the STSM.

For men, the participation effects of the Full-Time reform are non-negative for all deciles and all household types. This can be explained by the fact that men rarely work part-time and are therefore less affected by the abolishment of exemptions for marginal employment and increased transfer withdrawal rates while profiting from the subsidization of full-time employment. In contrast, the effect of the Full-Time reform on participation rates for women is either negative or zero in all income deciles.

Split into household types, the participation effects have the same sign as the hours changes for the Employment and Flat Tax reforms: they are non-positive for all household types and zero for single men for the Employment reform. For the Full-Time reform, participation effects are negative for all household types, while hours effects are positive for most household types. This shows that the incentives provided by this reform, lead households to change from part-time employment to full-time employment or unemployment. 
Table 5: Simulated Participation Effects of the Reform Scenarios by Household Types, Over the Income Distribution, and on Aggregate.

\begin{tabular}{lccccccccc}
\hline & \multicolumn{3}{c}{ Employment } & \multicolumn{3}{c}{ Full-Time } & \multicolumn{3}{c}{ Flat Tax } \\
& Women & Men & Total & Women & Men & Total & Women & Men & Total \\
\hline Changes in Participation Rates (in Percentage Points) & & & & & \\
Deciles of Net Equivalence Income & & & & & & & \\
1st & 0.0 & 1.0 & 0.4 & -1.7 & 2.6 & 0.0 & -0.7 & 2.1 & 0.4 \\
2nd & 0.3 & 0.0 & 0.2 & -0.3 & 0.0 & -0.2 & -1.8 & 0.0 & -1.1 \\
3rd & -0.5 & 0.0 & -0.3 & -1.4 & 0.0 & -0.8 & -3.0 & -0.4 & -2.0 \\
4th & 0.0 & 0.0 & 0.0 & -0.9 & 0.0 & -0.5 & -2.3 & -1.5 & -2.0 \\
5th & -0.6 & -0.7 & -0.6 & -0.3 & 0.0 & -0.2 & -3.8 & -2.6 & -3.2 \\
6th & -0.8 & 0.0 & -0.4 & 0.0 & 0.0 & 0.0 & -4.2 & -3.3 & -3.8 \\
7th & -0.6 & -0.6 & -0.6 & 0.0 & 0.0 & 0.0 & -6.3 & -1.8 & -4.1 \\
8t & -0.3 & -0.3 & -0.3 & 0.0 & 0.0 & 0.0 & -8.3 & -2.5 & -5.5 \\
9th & -0.5 & 0.0 & -0.3 & -0.3 & 0.0 & -0.1 & -6.0 & -2.4 & -4.2 \\
10th & -0.9 & -0.2 & -0.6 & 0.0 & 0.0 & 0.0 & -7.2 & -2.6 & -4.9 \\
By Household Type & & & & & & & & & \\
Couples, 0 Children & -0.5 & -0.2 & -0.3 & -0.5 & 0.2 & -0.1 & -4.5 & -1.2 & -2.8 \\
Couples, 1 Child & -0.3 & -0.1 & -0.2 & -0.5 & 0.2 & -0.2 & -4.6 & -1.0 & -2.8 \\
Couples,2+ Children & -0.4 & -0.1 & -0.2 & -0.5 & 0.2 & -0.2 & -4.5 & -1.0 & -2.8 \\
Singles, 0 Children & 0.0 & 0.0 & 0.0 & -0.2 & 0.0 & -0.1 & -6.2 & -5.6 & -5.9 \\
Singles, 1 Child & -0.9 & 0.0 & -0.8 & -0.5 & 0.0 & -0.4 & -3.2 & -8.0 & -3.7 \\
Singles, 2 Children & -0.8 & 0.0 & -0.8 & -1.7 & 0.0 & -1.5 & -1.7 & -8.3 & -2.3 \\
All Households & -0.4 & -0.1 & -0.3 & -0.4 & 0.2 & -0.2 & -4.5 & -1.8 & -3.3 \\
\hline
\end{tabular}

Source: Own calculations based on the SOEP v291 (2012) and a modified version of the STSM.

\subsection{Income Effects and Welfare}

Table 6 shows annual changes in average incomes and compensating variations, i.e. the amount of money that would have to be given or taken away from a household after a reform for it to reach the utility level it had before the reform. We adjust these measures by the OECD equivalence scale for different household types. Positive compensating variations indicate welfare gains. The compensating variations are generally larger than the income changes when households reduce their labor supply.

All three reforms lead to income and welfare gains for lone parents. The Full-Time reform leads to both income and welfare gains for all household types. The Employment reform leads to welfare gains for all household types except for childless singles, while only lone parents gain financially. The Flat Tax induces the most radical effects: because transfers are no longer adjusted for household size, people with children gain substantially, the compensating variation of singles 
with at least two children is more than 2,200 Euro. On the other hand, singles without children have a negative compensating variation of more than 400 Euro because of the increase in tax rates. The income loss for this group is close to 2,000 Euro, but it is partially offset in welfare terms by a substantial reduction in labor supply.

Table 6: Simulated Income and Welfare Changes of the Reform Scenarios Adjusted by the OECD Equivalence Scale by Household Types and on Aggregate in Euro per Year and Household.

\begin{tabular}{lcccccc}
\hline & \multicolumn{2}{c}{ Employment } & \multicolumn{2}{c}{ Full-Time } & \multicolumn{2}{c}{ Flat Tax } \\
& $\begin{array}{l}\text { Income } \\
\text { Change }\end{array}$ & CV & Income & CV & Income & CV \\
& Change & & Change & \\
\hline Couples, 0 Children & -172 & 84 & 451 & 501 & 88 & 972 \\
Couples, 1 Child & -93 & 139 & 447 & 492 & 255 & 1066 \\
Couples, 2+ Children & -102 & 140 & 434 & 491 & 241 & 1055 \\
Singles, 0 Children & -379 & -128 & 485 & 483 & -1987 & -469 \\
Singles, 1 Child & 5 & 640 & 282 & 282 & 325 & 1832 \\
Singles, 2+ Children & 433 & 579 & 85 & 69 & 1682 & 2249 \\
All Households & -182 & 81 & 444 & 473 & -423 & 662 \\
\hline
\end{tabular}

Notes: Our sample comprises households with members who have flexible labor supply.

Source: Own calculations based on the SOEP v291 (2012) and a modified version of the STSM.

Table 7 depicts income and welfare changes adjusted by the OECD equivalence scale over the income distribution. The Employment reform clearly benefits those with low incomes at the cost of those with higher incomes. Compensating variations for the lowest decile are more than 1,900 Euro on average and 1,600 Euro for the 2nd decile, the average compensating variations decrease steadily with increasing income. While households in the 5th decile still gain on average, those in the 6th decile lose and the compensating variation for the 10th decile is about -1,500 Euro on average.

In the Full-Time reform all deciles of the income distribution gain both in terms of income and welfare, the highest gains are reached by the 3rd to 5th income decile, while the upper deciles gain less from the employment subsidy. 
Table 7: Simulated Income and Welfare Changes of the Reform Scenarios Adjusted by the OECD Equivalence Scale over the Income Distribution and on Aggregate.

\begin{tabular}{lcccccc}
\hline \multicolumn{2}{c}{$\begin{array}{c}\text { Employment } \\
\text { Income } \\
\text { Change }\end{array}$} & CV & \multicolumn{2}{c}{ Full-Time } & \multicolumn{2}{c}{ Flat Tax } \\
Income & CV & Income & CV \\
Change & & Change & \\
\hline Deciles of Net Equivalence & Income \\
1st & 1943 & 1920 & 229 & 98 & 4296 & 4210 \\
2nd & 1558 & 1600 & 515 & 511 & 4065 & 4078 \\
3rd & 941 & 992 & 741 & 747 & 2941 & 3330 \\
4th & 389 & 613 & 750 & 805 & 2178 & 2561 \\
5th & -73 & 134 & 613 & 696 & 1067 & 1830 \\
6th & -852 & -294 & 459 & 543 & -48 & 1165 \\
7th & -928 & -498 & 424 & 463 & -948 & 48 \\
8th & -1137 & -885 & 348 & 375 & -2822 & -998 \\
9th & -1418 & -1215 & 242 & 264 & -4531 & -2827 \\
10th & -2209 & -1515 & 117 & 228 & -10387 & -6715 \\
All Households & -182 & 81 & 444 & 473 & -423 & 662 \\
\hline
\end{tabular}

Notes: Our sample comprises households with members who have flexible labor supply.

Source: Own calculations based on the SOEP v291 (2012) and a modified version of the STSM.

The Flat Tax reform leads to income and welfare gains for the lower five deciles. On average, incomes in the 6th and 7th decile decrease but in welfare terms this is more than offset by the increase in leisure. For the upper three deciles both the income changes and the compensating variations are negative on average. The largest welfare gains are registered for the 1st decile (compensating variation of more than 4,200 Euro), while the highest average welfare loss is estimated with about 6,700 Euro for the 10th decile.

The average welfare measures in the bottom line of Table 7 imply that each person is given the same weight. Alternatively, aggregate welfare changes may also be evaluated by a social welfare function with individual weights depending on some function of individual income. Figure 5 and Table 9 in the appendix show aggregate welfare gains for different values of a parameter for redistributive taste $v$. The weighted average compensating variation $\left(w_{c v}\right)$ is given by

$$
w_{c v}=\frac{\sum_{i=1}^{N} c v_{i} / y_{i}^{v}}{\sum_{i=1}^{N} 1 / y_{i}^{v}},
$$

where $y$ denotes income and $c v$ denotes the compensating variation, both adjusted by the OECD equivalence scale. The higher is $v$, the higher is the welfare weight assigned to individuals with 


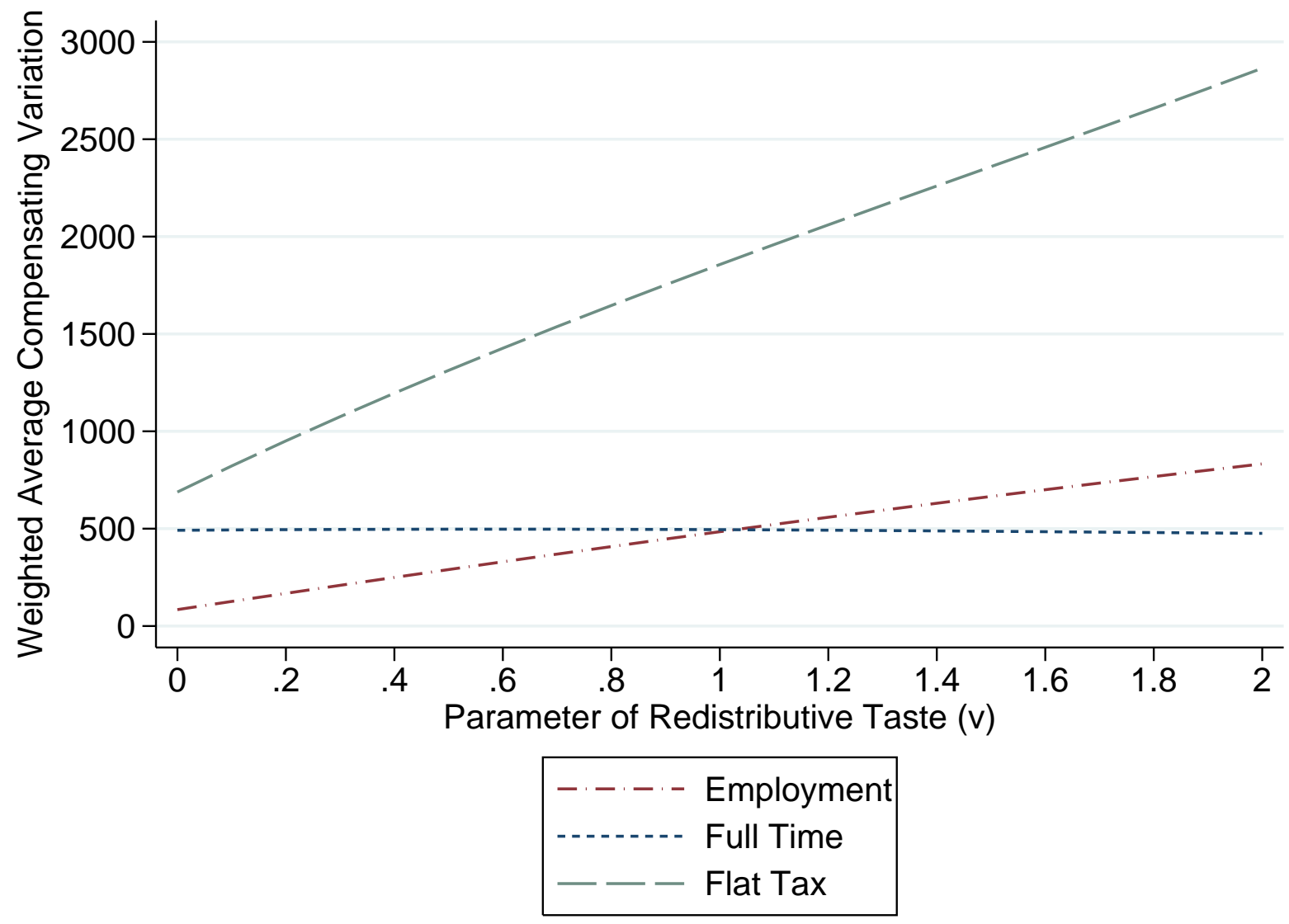

Figure 5: Average Weighted Compensated Variations of Reforms. Source: Own calculations based on the SOEP v291 (2012) and a modified version of the STSM.

lower incomes. $v=0$ leads to the utilitarian social welfare function, which assigns the same weight to all members of society. If $v=1, w_{c v}$ is a weighted mean with weights $y_{i}^{-1}$. If $v \rightarrow \infty, w_{c v}$ converges to the Rawlsian social welfare function.

All three reforms lead to average welfare gains for all values of $v$. Using a utilitarian social welfare function, the aggregate welfare gains of the Employment reform are relatively small and the Full-Time and Flat Tax reform lead to average welfare gains of about 500 and 700 Euro, respectively. The welfare gains of the Flat Tax reform are monotonically increasing with $v$ as it leads to the highest welfare gains for low income households and welfare losses for higher income households. Aggregate welfare gains of the Full-Time reform decrease smoothly, because the employment subsidy starts at rather high levels of income and the transfer withdrawal rates are increased. Welfare gains of the Employment reform increase with $v$. The Full-Time reform dominates the Employment reform in welfare terms for $v<1$, the reverse is true for higher values of $v$. The Flat Tax reform dominates both Full-Time and Employment at all levels of $v$. 


\section{Summary and Conclusions}

In this paper we have analyzed three budgetary neutral reforms of the German tax and transfer system-two reforms that employ employment subsidies to improve work incentives for people with low incomes and a Flat Tax reform with a basic income equal to the current level of Unemployment Benefit II. The first two reforms stipulate employment subsidies of 1,560 Euro per year for people working at least 10 (Employment) or 30 (Full-Time) hours a week, respectively. In addition, the 10 hours reform involves a reduction of marginal transfer withdrawal rates. It is financed by abolishing social security exemptions for marginal employment and increasing marginal tax rates. The Full-Time reform is financed by abolishing social security exemptions for marginal employment and increasing marginal transfer withdrawal rates.

Using a structural labor supply model, we have estimated labor supply reactions and welfare effects of the reform scenarios. We find that all three reforms increase labor supply in the first decile of the income distribution. However, the Flat Tax reform and the reform designed to increase incentives for labor market participation (Employment) reduce labor supply of households at most other income deciles, while the Full-Time reform has a negligible effect on overall labor supply. The Flat Tax scenario reduces overall labor supply by about $4.9 \%$, while the Employment reform scenario has only a relatively small negative effect on labor supply. With equal welfare weights, aggregate welfare gains are realizable under all three reforms. The stronger the redistributive taste, the higher are the welfare gains of the flat tax reform.

A word of caution about the limitations of the model employed for our analysis is in order as the application of a dynamic labor supply model could result in lower potential welfare gains. First, empirical studies of labor supply tend to find small labor supply elasticities (see Meghir and Phillips 2010) and this includes structural models limited to one period. However, this common finding is challenged by models that account for learning on the job and often find substantially larger elasticities (see Keane and Rogerson 2012). In the presence of larger labor supply elasticities than the ones estimated by the model applied in this study, the basic income of the Flat Tax reform as well as the employment subsidy of the Employment reform would have to be financed by even larger tax increases, which in turn would reduce the welfare gains of these reforms. However, Blundell et al. (2013) estimate a dynamic model for women that accounts for learning on the job and find elasticities similar to the ones obtained with a static one-period model.

Moreover, the static model does not account for uncertainty. The welfare gains of the Flat Tax are smaller when households are forward looking decision makers and future income is uncertain. 
Rostam-Afschar and Yao (2014) show that the social insurance provided by the progressivity of the German tax and transfer system generates additional welfare. The median household would have to be compensated by about 65,000 Euro or $12 \%$ of lifetime income to choose the revenue neutral flat tax instead of the progressive tax.

Keeping these caveats in mind, we conclude that it is difficult to reform the German tax and transfer system in a way that improves work incentives for low income households without decreasing overall labor supply and violating budgetary neutrality. However, aggregate welfare improvements are possible through more redistribution to low income households and households with children. A flat-tax with unconditional basic income may achieve these aims for Germany.

\section{References}

AABERge, R., AND U. COLOMBino (2014): "Labour supply models," in Handbook of microsimulation modelling, ed. by C. O’Donoghue, vol. 293 of Contributions to economic analysis, 167221. Emerald Group Publishing. Cited on page 16.

Aaberge, R., U. Colombino, and S. Strøm (2000): "Labor supply responses and welfare effects from replacing current tax rules by a flat tax: empirical evidence from Italy, Norway and Sweden,” J. Population Econ., 13(4), 595-621. Cited on page 2.

Aaberge, R., J. K. DagsviK, And S. StrøM (1995): "Labor supply responses and welfare effects of tax reforms," Scand. J. Econ., 97(4), 635-659. Cited on page 16.

AtKinson, A. (2005): "How basic income is moving up the policy agenda: news from the future," in Promoting income security as a right: Europe and North America, ed. by G. Standing, 41-52. Anthem Press, London. Cited on page 1.

Bargain, O., M. Caliendo, P. HaAn, and K. Orsini (2010): ““Making work pay” in a rationed labor market," J. Population Econ., 23(1), 323-351. Cited on page 2.

Bartels, C., And N. Pestel (2015): "The impact of short- and long-term participation tax rates on labor supply," IZA Discussion Paper 9151, Institute for the Study of Labor. Cited on page 14. 
Blundell, R., M. C. Dias, C. Meghir, and J. M. ShaW (2013): "Female labour supply, human capital and welfare reform," Working Paper 19007, National Bureau of Economic Research. Cited on page 25.

Blundell, R., AND A. Shephard (2012): "Employment, hours of work and the optimal taxation of low-income families," Rev. Econ. Stud., 79(2), 481-510. Cited on page 2.

Colombino, U. (2009): "Evaluating alternative basic income mechanisms: a simulation for European countries,” Discussion Paper 578, Research Department of Statistics Norway. Cited on page 1 .

Colombino, U., M. Locatelli, E. Narazani, and C. O’Donoghue (2010): “Alternative basic income mechanisms: an evaluation exercise with a microeconometric model," Basic Income Stud., 5(1), 1-31. Cited on page 2.

Colombino, U., And E. NARAZAni (2013): "Designing a universal income support mechanism for Italy: an exploratory tour,” Basic Income Stud., 8(1), 1-17. Cited on page 2.

Colombo, G., R. Schnabel, and S. Schubert (2008): "Basic income reform in Germany: a microsimulation-age analysis," retrieved 11/17/2014 from http://www.aiel.it/ 0ld/bacheca/BRESCIA/papers/colombo.pdf. Cited on page 2.

Creedy, J., And G. KALB (2005): “Discrete hours labour supply modelling: specification, estimation and simulation,” J. Econ. Surveys, 19(5), 697-734. Cited on page 18.

Franz, W., N. Guertzgen, S. Schubert, and M. Clauss (2012): “Assessing the employment effects of the German welfare reform: an integrated CGE-microsimulation approach," Appl. Econ., 44(19), 2403-2421. Cited on page 1.

FRIEDMAN, M. (2002): Capitalism and freedom: fortieth anniversary edition. University of Chicago Press, Chicago. Cited on page 1.

Fuest, C., A. Peichl, And T. Schaefer (2008): "Is a flat tax reform feasible in a grownup democracy of Western Europe? A simulation study for Germany," Int. Tax Public Finance, 15(5), 620-636. Cited on page 2.

HeCKMAN, J. J. (1979): "Sample selection bias as a specification error," Econometrica, 47(1), 153-161. Cited on page 16. 
HorstschräER, J., M. Clauss, And R. Schnabel (2010): “An unconditional basic income in the family context: labor supply and distributional effects," Discussion Paper 10-091, Center for European Economic Research. Cited on page 2.

Hotz, V. J., AND J. K. Scholz (2003): “The earned income tax credit,” in Means-tested transfer programs in the United States, ed. by R. A. Moffitt, 141-198. University of Chicago Press. Cited on page 2 .

Immervoll, H., H. J. Kleven, C. T. Kreiner, and E. Saez (2007): "Welfare reform in European countries: a microsimulation analysis," Econ. J., 117(516), 1-44. Cited on pages 2 and 14 .

Jessen, R., And D. RostAm-Afschar (2014): "GRAPH3D: stata module to draw colored, scalable, rotatable 3D plots," Statistical Software Components, Boston College Department of Economics, http://ideas.repec.org/c/boc/bocode/s457929.html. Cited on page 10.

KeAne, M. P. (1995): “A new idea for welfare reform," Federal Reserve Bank of Minneapolis Quarterly Review, 19(Spr), 2-28. Cited on page 2.

Keane, M. P., And R. Rogerson (2012): "Reconciling micro and macro labor supply elasticities: a structural perspective,” Economics Paper 2012-W12, Economics Group, Nuffield College, University of Oxford. Cited on page 25.

KIRCHHOF, P. (2003): Einkommensteuergesetzbuch: Ein Vorschlag zur Reform der Einkommenund Körperschaftsteuer. C. F. Müller Verlag, Heidelberg. Cited on page 1.

(2011): Bundessteuergesetzbuch: Ein Reformentwurf zur Erneuerung des Steuerrechts. C. F. Müller Verlag, Heidelberg. Cited on page 1.

MCFADDEN, D. (1974): "Conditional logit analysis of qualitative choice behavior," in Frontiers in econometrics, ed. by P. Zarembka, 105-142. Academic Press, New York. Cited on page 17.

Meghir, C., And D. Phillips (2010): "Labour supply and taxes," in Dimensions of tax design, ed. by J. Mirrlees et al., vol. 1 of Mirrlees review. Oxford University Press. Cited on page 25.

Munnell, A. H. (ed.) (1987): Lessons from the income maintenance experiments, vol. 30 of Federal Reserve Bank of Boston conference series, Boston. Cited on page 1. 
Prescott, D., R. Swidinsky, And D. A. Wilton (1986): "Labour supply estimates for lowincome female heads of household using mincome data," Can. J. Econ., 19(1), 134-141. Cited on page 1 .

Rostam-Afschar, D., AND J. YAO (2014): "Progressive taxation and precautionary saving," mimeo, Freie Universität Berlin. Cited on page 26.

Steiner, V., K. Wrohlich, P. HaAn, And J. Geyer (2012): "Documentation of the taxbenefit microsimulation model STSM: version 2012," Data Documentation 63, German Institute for Economic Research. Cited on page 16.

StraubhaAR, T. (ed.) (2008): Bedingungsloses Grundeinkommen und Solidarisches Bürgergeld: mehr als sozialutopische Konzepte. Hamburg University Press, Hamburg. Cited on page 2 .

VAN SOEST, A. (1995): “Structural models of family labor supply: a discrete choice approach,” J. Human Res., 30(1), 63-88. Cited on page 16.

WAgner, G. G., J. R. Frick, And J. Schupp (2007): “The German Socio-Economic Panel Study (SOEP): scope, evolution and enhancements," Schmollers Jahr., 127(1), 139-169. Cited on page 16. 
7 Appendix

Figures (next page) 


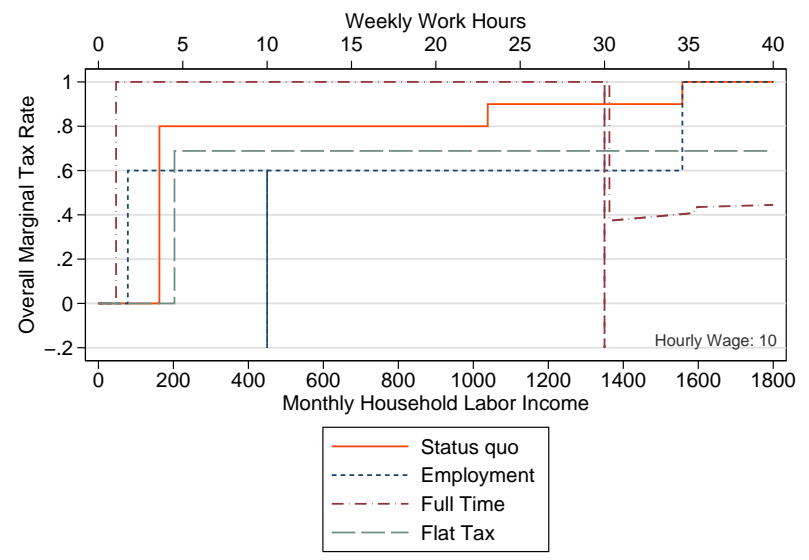

(a) Single Person with One Child

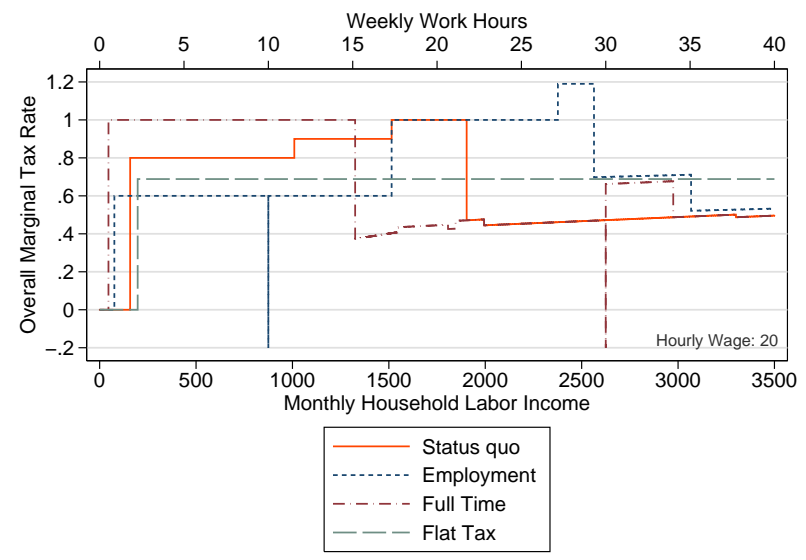

(b) Single Person with One Child

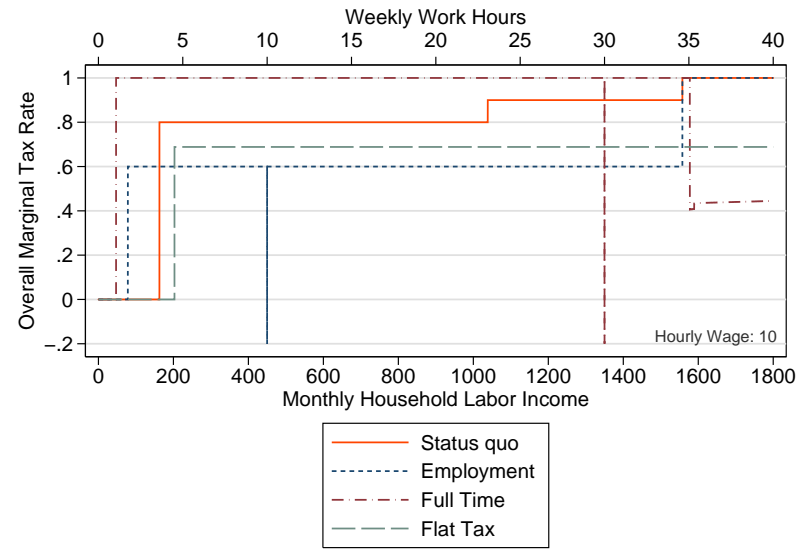

(c) Single Person with Two Children

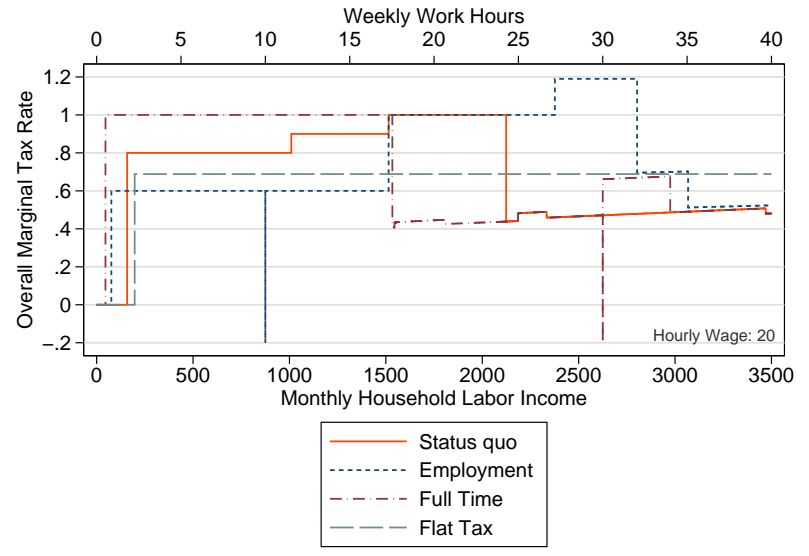

(d) Single Person with Two Children

Figure 6: Marginal Tax Rates by Monthly Household Gross Labor Income and Weekly Working Hours in Germany, 2011. Source: Own calculations based on a modified version of the STSM. 


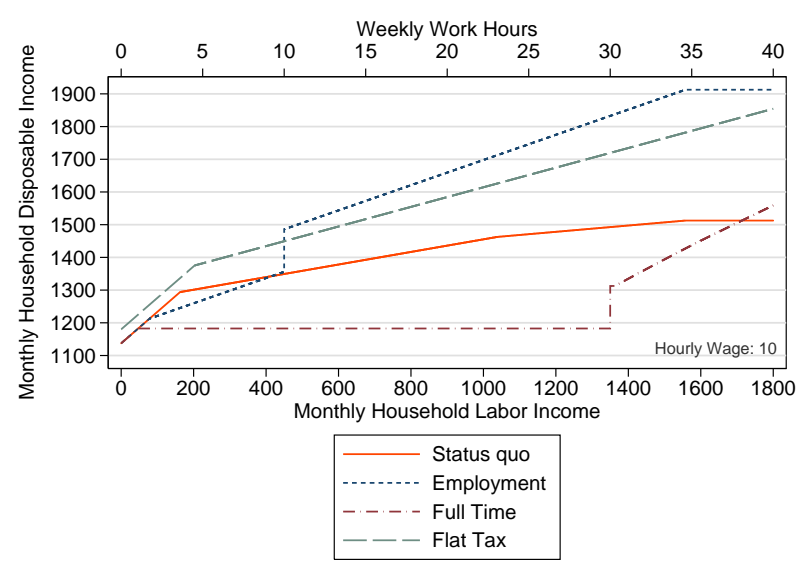

(a) Single Person with One Child

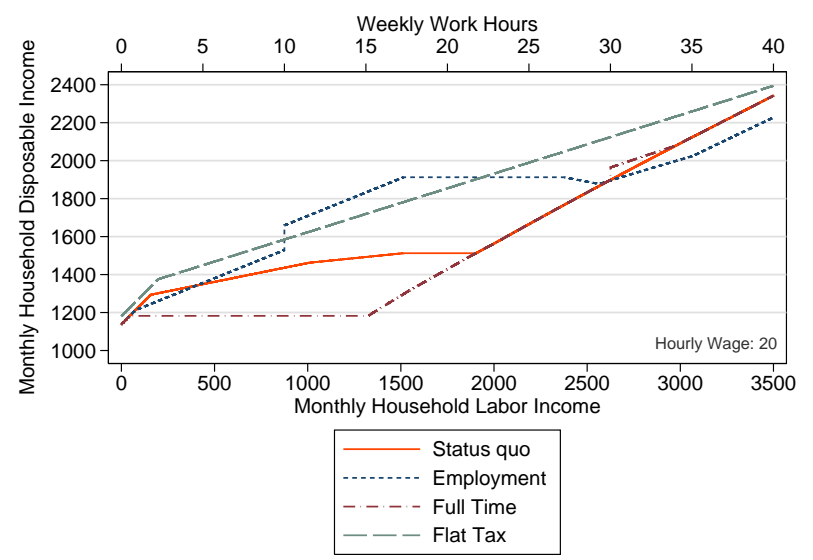

(b) Single Person with One Child

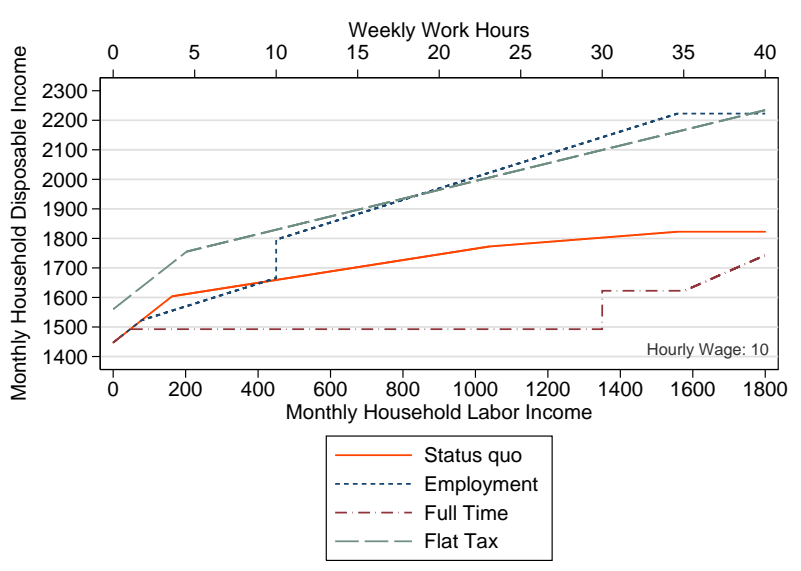

(c) Single Person with Two Children

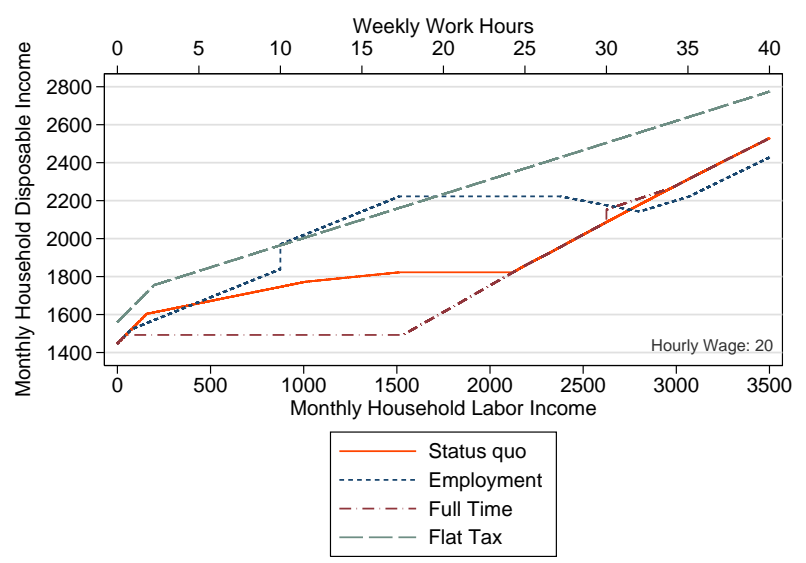

(d) Single Person with Two Children

Figure 7: Budget Constraint by Monthly Household Gross Labor Income and Weekly Working Hours in Germany, 2011. Source: Own calculations based on a modified version of the STSM. 


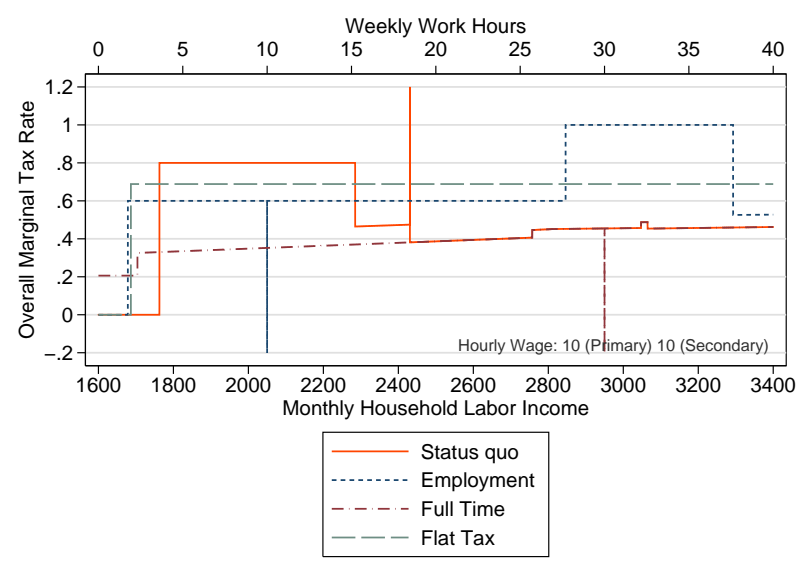

(a) Married Household without Children

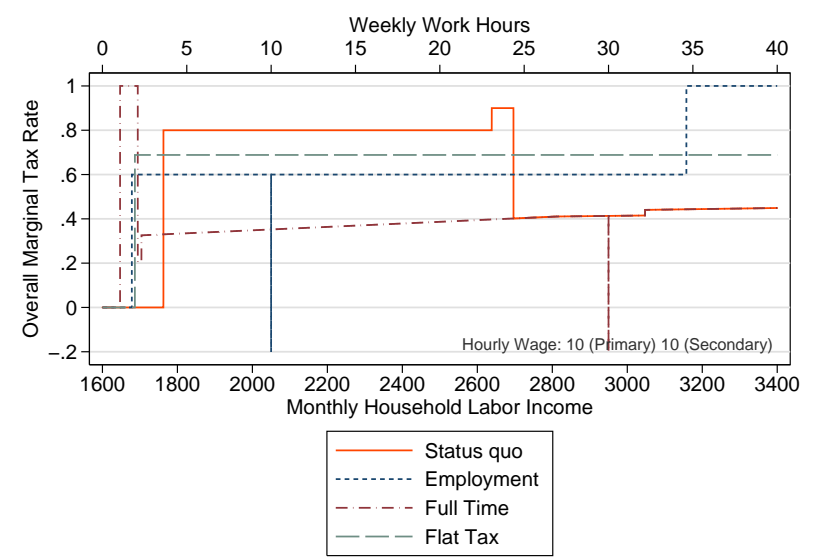

(c) Married Household with One Child

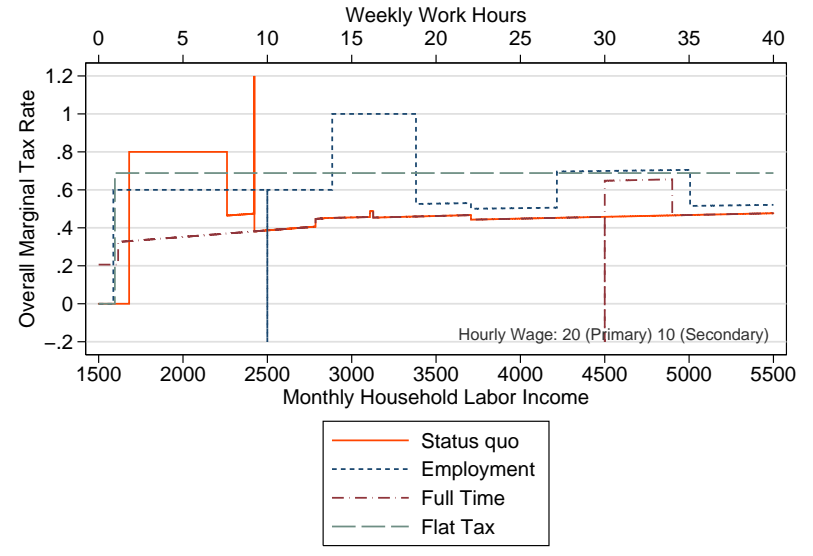

(b) Married Household without Children

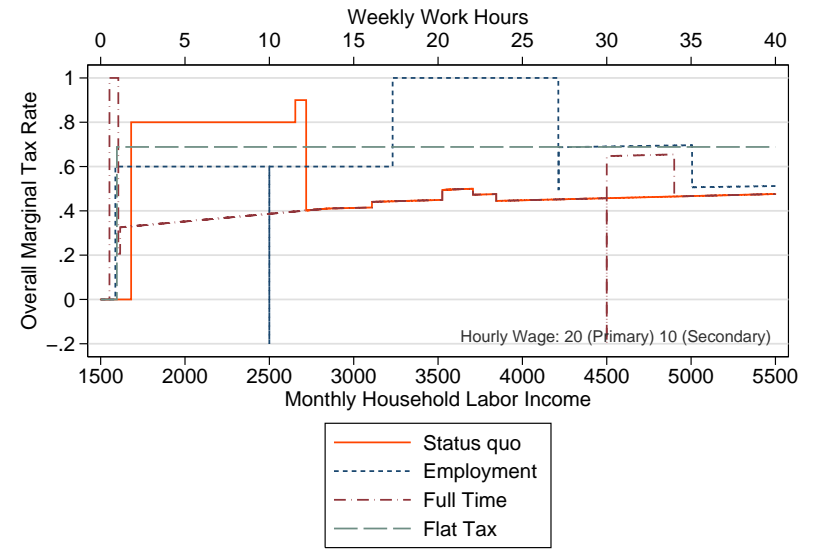

(d) Married Household with One Child

Figure 8: Marginal Tax Rates by Monthly Household Gross Labor Income and Weekly Working Hours in Germany, 2011. Source: Own calculations based on a modified version of the STSM. 


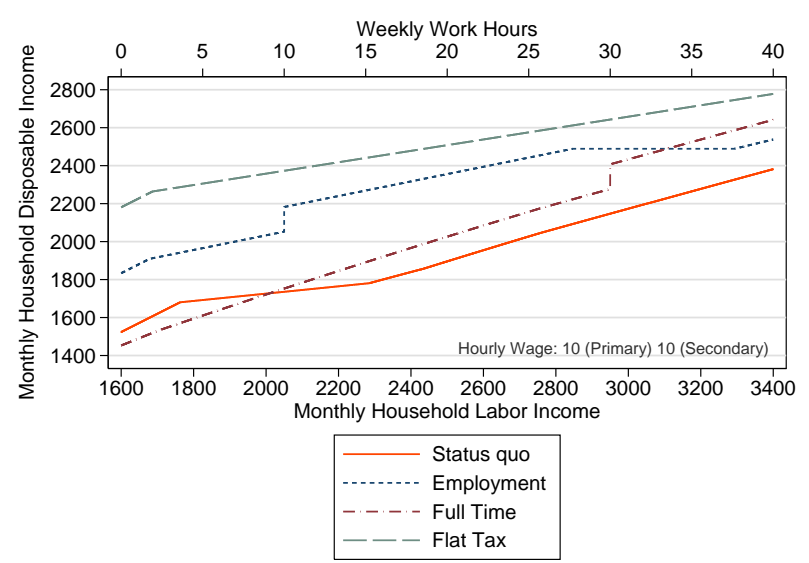

(a) Married Household without Children

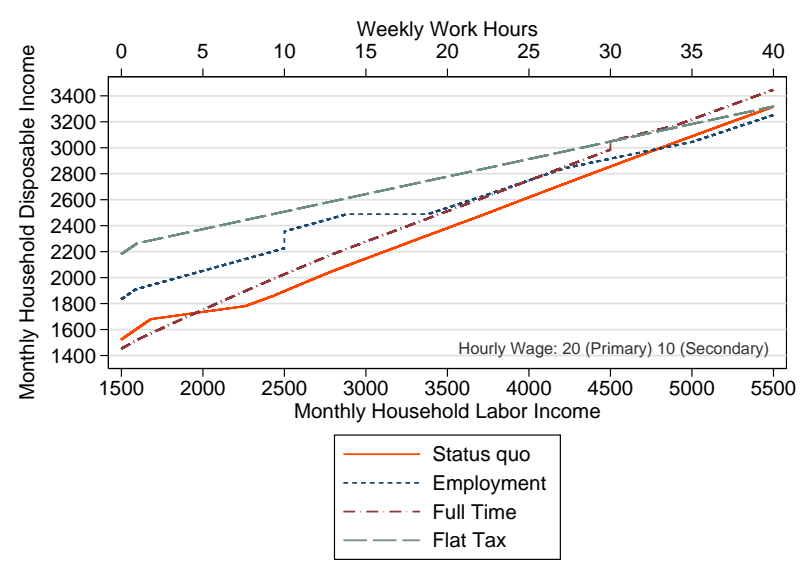

(b) Married Household without Children

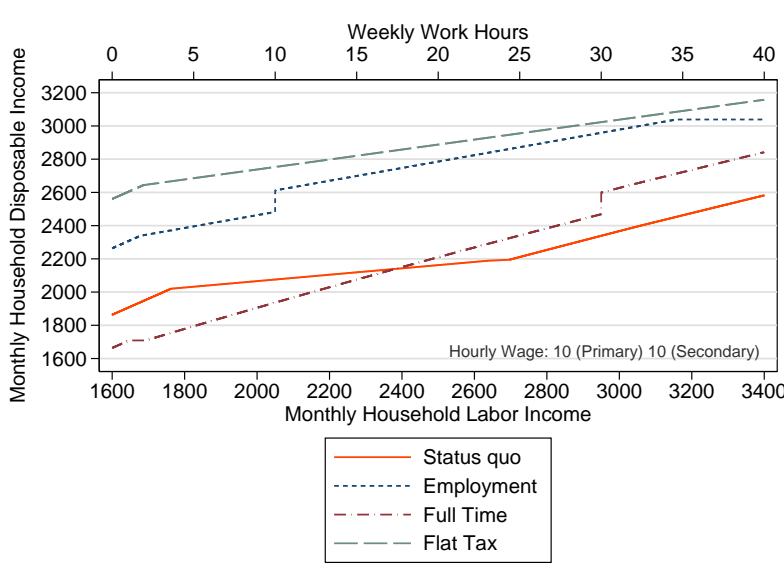

(c) Married Household with One Child

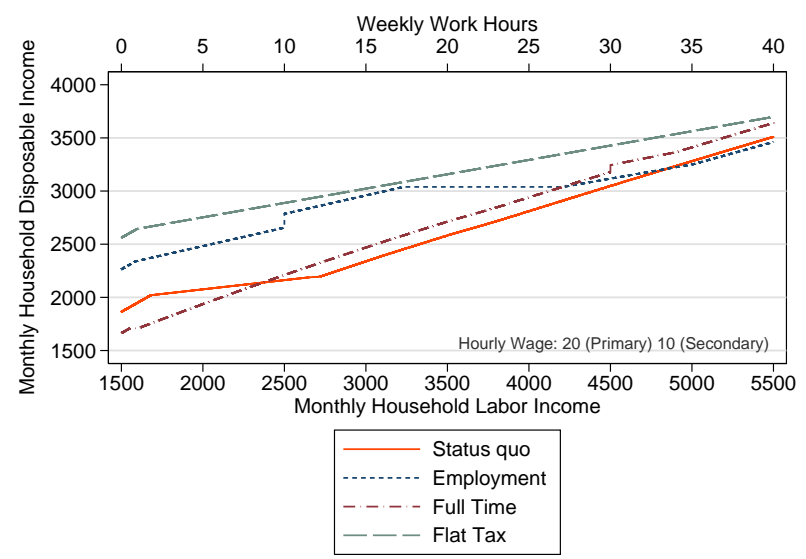

(d) Married Household with One Child

Figure 9: Budget Constraint by Monthly Household Gross Labor Income and Weekly Working Hours in Germany, 2011. Source: Own calculations based on a modified version of the STSM. 

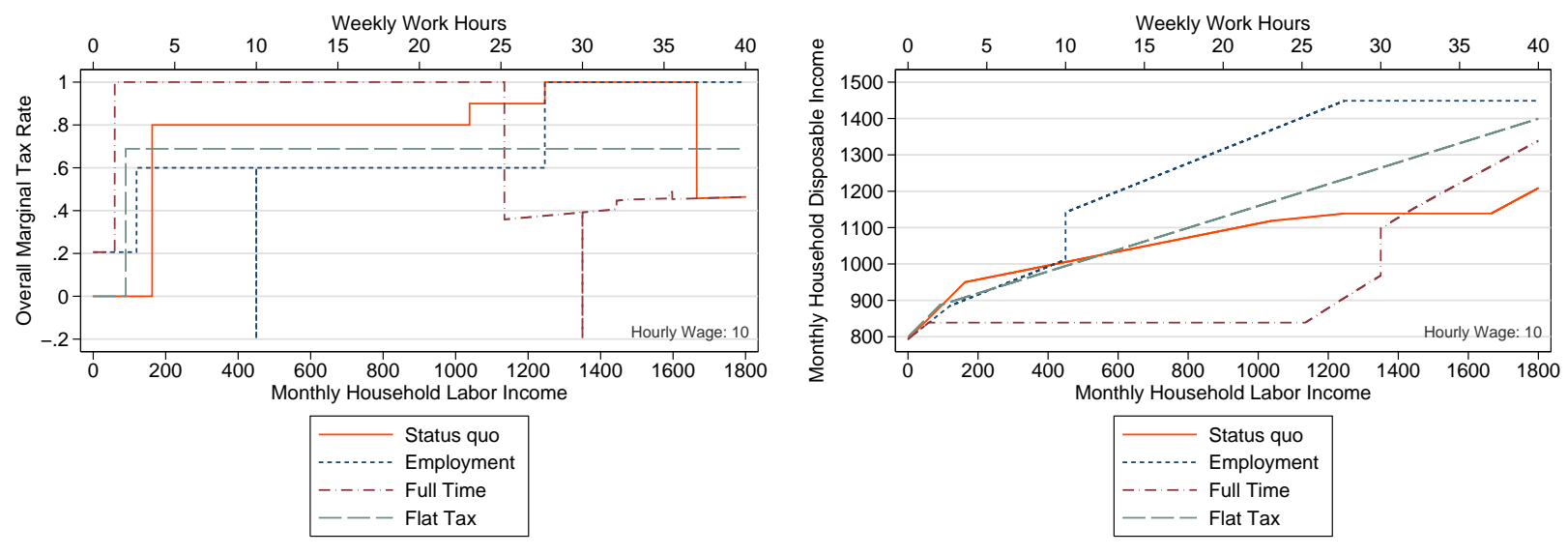

(a) Single Person without Children
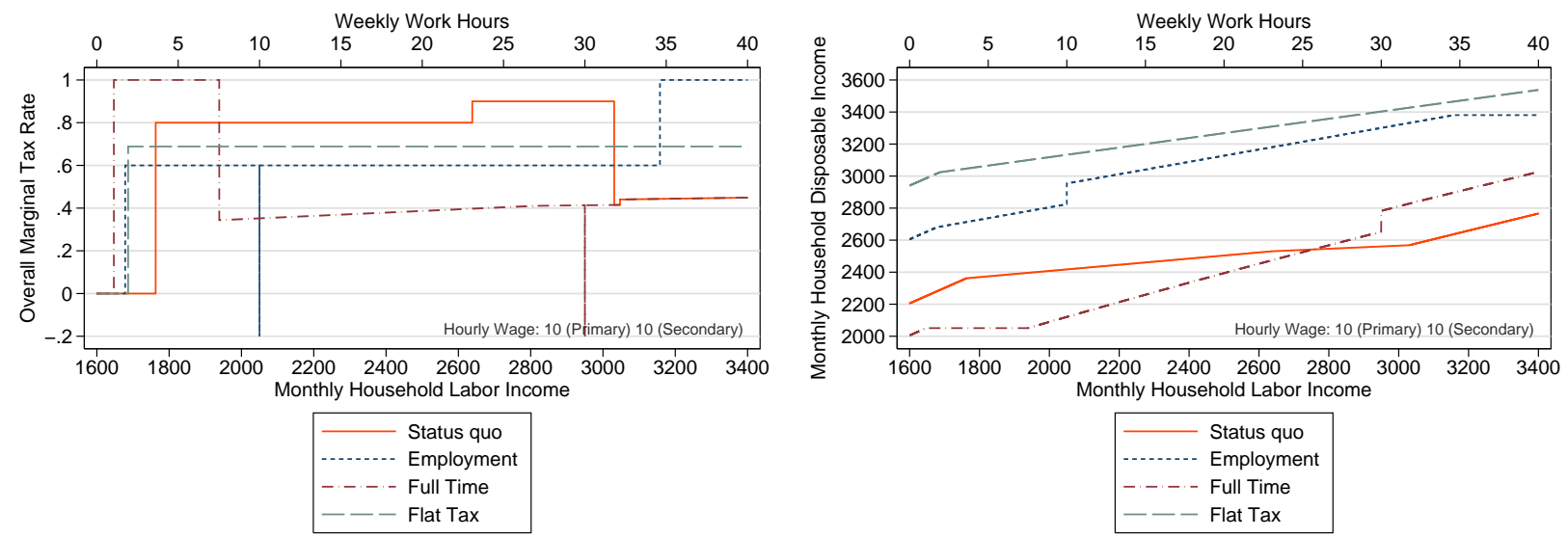

(b) Married Household with Two Children

Figure 10: Marginal Tax Rates and Budget Constraint by Monthly Household Gross Labor Income and Weekly Working Hours in Germany, 2011. Source: Own calculations based on a modified version of the STSM. 
Tables (next page) 
Table 8: Estimation Results for Labor Supply Model, Dependent Variable: Hours Chosen.

\begin{tabular}{|c|c|c|c|c|c|}
\hline Variables & $\begin{array}{l}\text { Flexible } \\
\text { Couples }\end{array}$ & $\begin{array}{l}\text { Women with } \\
\text { Inflexible } \\
\text { Spouse }\end{array}$ & $\begin{array}{l}\text { Men with } \\
\text { Inflexible } \\
\text { Spouse }\end{array}$ & $\begin{array}{l}\text { Single } \\
\text { Men }\end{array}$ & $\begin{array}{l}\text { Single } \\
\text { Women }\end{array}$ \\
\hline Log Net Income & $\begin{array}{l}4.018 \\
(2.858)\end{array}$ & $\begin{array}{l}-5.930^{*} \\
(2.318)\end{array}$ & $\begin{array}{c}2.983 \\
(9.246)\end{array}$ & $\begin{array}{l}-1.705 \\
(2.596)\end{array}$ & $\begin{array}{l}-3.338 \\
(2.319)\end{array}$ \\
\hline$(\text { Log Net Income })^{2}$ & $\begin{array}{l}0.193^{*} \\
(0.0777)\end{array}$ & $\begin{array}{c}0.198^{*} \\
(0.0884)\end{array}$ & $\begin{array}{l}-0.0526 \\
(0.351)\end{array}$ & $\begin{array}{c}0.0785 \\
(0.0667)\end{array}$ & $\begin{array}{l}0.237^{* * *} \\
(0.0659)\end{array}$ \\
\hline Log Net Income $\times$ East & $\begin{array}{l}3.261 \\
(2.507)\end{array}$ & $\begin{array}{l}-11.83 \\
(6.587)\end{array}$ & $\begin{array}{l}-2.336 \\
(8.167)\end{array}$ & $\begin{array}{l}5.420^{* *} \\
(1.952)\end{array}$ & $\begin{array}{l}1.027 \\
(1.877)\end{array}$ \\
\hline Log Net Income $)^{2} \times$ East & $\begin{array}{l}-0.232 \\
(0.132)\end{array}$ & $\begin{array}{c}0.587 \\
(0.339)\end{array}$ & $\begin{array}{l}0.0650 \\
(0.413)\end{array}$ & $\begin{array}{c}-0.337^{* *} \\
(0.117)\end{array}$ & $\begin{array}{c}-0.0691 \\
(0.116)\end{array}$ \\
\hline Log Net Income $\times$ German Female & $\begin{array}{l}0.428 \\
(0.312)\end{array}$ & $\begin{array}{l}2.614^{*} \\
(1.050)\end{array}$ & $\begin{array}{l}-0.124 \\
(0.387)\end{array}$ & & $\begin{array}{c}0.380 \\
(0.412)\end{array}$ \\
\hline Log Leisure Female & $\begin{array}{l}62.91^{* * *} \\
(6.400)\end{array}$ & $\begin{array}{c}56.56^{* * *} \\
(6.962)\end{array}$ & & & $\begin{array}{c}55.44^{* * *} \\
(7.998)\end{array}$ \\
\hline $\begin{array}{l}\text { Log Net Income } \\
\times \text { Log Leisure Female }\end{array}$ & $\begin{array}{l}-0.370 \\
(0.262)\end{array}$ & $\begin{array}{c}-0.00946 \\
(0.236)\end{array}$ & & & $\begin{array}{r}-0.0151 \\
(0.370)\end{array}$ \\
\hline Log Leisure Female ${ }^{2}$ & $\begin{array}{l}-6.585^{* * *} \\
(0.541)\end{array}$ & $\begin{array}{c}-6.257^{* * *} \\
(0.730)\end{array}$ & & & $\begin{array}{c}-6.529^{* * *} \\
(0.704)\end{array}$ \\
\hline Log Leisure Female $\times$ German Female & $\begin{array}{l}-0.6885 \\
(0.384)\end{array}$ & $\begin{array}{c}-0.0200 \\
(0.737)\end{array}$ & & & $\begin{array}{l}-1.109 \\
(0.608)\end{array}$ \\
\hline Age Female $x$ Log Leisure Female & $\begin{array}{l}-0.218^{* *} \\
(0.0720)\end{array}$ & $\begin{array}{l}-0.442^{* * *} \\
(0.0884)\end{array}$ & & & $\begin{array}{l}-0.144 \\
(0.0853)\end{array}$ \\
\hline Age $^{2} \times$ Log Leisure Female & $\begin{array}{l}0.00374^{* * *} \\
(0.000837)\end{array}$ & $\begin{array}{l}0.00633^{* * *} \\
(0.000992)\end{array}$ & & & $\begin{array}{c}0.00259^{* *} \\
(0.000986)\end{array}$ \\
\hline Log Leisure Female $\times$ Disability I & $\begin{array}{l}0.192 \\
(0.348)\end{array}$ & $\begin{array}{l}0.944^{*} \\
(0.435)\end{array}$ & & & $\begin{array}{l}1.053^{* *} \\
(0.403)\end{array}$ \\
\hline Log Leisure Female $\times$ Disability II & $\begin{array}{l}0.729 \\
(0.666)\end{array}$ & $\begin{array}{l}1.868^{*} \\
(0.816)\end{array}$ & & & $\begin{array}{l}1.546^{*} \\
(0.617)\end{array}$ \\
\hline Log Leisure Female $\times$ East & $\begin{array}{l}-15.48^{* * *} \\
(2.506)\end{array}$ & $\begin{array}{r}-1.480^{* *} \\
(0.468)\end{array}$ & & & $\begin{array}{l}-0.515 \\
(0.456)\end{array}$ \\
\hline $\begin{array}{l}\text { Log Leisure Female } \\
\quad \times \text { Children Under } 3 \text { Years }\end{array}$ & $\begin{array}{l}4.649^{* * *} \\
(0.292)\end{array}$ & $\begin{array}{c}3.958^{* * *} \\
(0.420)\end{array}$ & & & $\begin{array}{l}4.393^{* * *} \\
(0.6885)\end{array}$ \\
\hline $\begin{array}{l}\text { Log Leisure Female } \\
\quad \times \text { Children } 7 \text { to } 16 \text { Years }\end{array}$ & $\begin{array}{l}1.888^{* * *} \\
(0.192)\end{array}$ & $\begin{array}{c}1.811^{* * *} \\
(0.289)\end{array}$ & & & $\begin{array}{c}1.202^{* * *} \\
(0.314)\end{array}$ \\
\hline $\begin{array}{l}\text { Log Leisure Female } \\
\quad \times \text { Children } 4 \text { to } 6 \text { Years }\end{array}$ & $\begin{array}{l}2.007^{* * *} \\
(0.266)\end{array}$ & $\begin{array}{c}1.977^{* * *} \\
(0.420)\end{array}$ & & & $\begin{array}{c}2.148^{* * *} \\
(0.487)\end{array}$ \\
\hline $\begin{array}{l}\text { Log Leisure Female } \\
\quad \times \text { Children over } 17 \text { Years }\end{array}$ & $\begin{array}{l}1.009^{* * *} \\
(0.189)\end{array}$ & $\begin{array}{l}0.829^{* *} \\
(0.267)\end{array}$ & & & $\begin{array}{l}-0.561 \\
(0.323)\end{array}$ \\
\hline Female Part Time I & $\begin{array}{l}-1.087^{* * *} \\
(0.0722)\end{array}$ & $\begin{array}{c}-1.406^{* * *} \\
(0.106)\end{array}$ & & & $\begin{array}{c}-2.185^{* * *} \\
(0.146)\end{array}$ \\
\hline Female Part Time II & $\begin{array}{l}-0.890^{* * *} \\
(0.0725)\end{array}$ & $\begin{array}{c}-1.079^{* * *} \\
(0.101)\end{array}$ & & & $\begin{array}{l}-1.515^{* * *} \\
(0.0977)\end{array}$ \\
\hline
\end{tabular}




\begin{tabular}{|c|c|c|c|c|c|}
\hline Variables & $\begin{array}{l}\text { Flexible } \\
\text { Couples }\end{array}$ & $\begin{array}{l}\text { Women with } \\
\text { Inflexible } \\
\text { Spouse }\end{array}$ & $\begin{array}{c}\text { Men with } \\
\text { Inflexible } \\
\text { Spouse }\end{array}$ & $\begin{array}{l}\text { Single } \\
\text { Men }\end{array}$ & $\begin{array}{l}\text { Single } \\
\text { Women }\end{array}$ \\
\hline Log Net Income $\times$ German Male & $\begin{array}{l}0.656 \\
(0.461)\end{array}$ & $\begin{array}{l}-0.139 \\
(0.250)\end{array}$ & $\begin{array}{l}-0.593 \\
(1.695)\end{array}$ & $\begin{array}{l}0.0380 \\
(0.544)\end{array}$ & \\
\hline Log Leisure Male $\times$ Log Net Income & $\begin{array}{l}-1.447^{* * *} \\
(0.292)\end{array}$ & & $\begin{array}{l}-0.0206 \\
(0.590)\end{array}$ & $\begin{array}{c}0.201 \\
(0.412)\end{array}$ & \\
\hline Log Leisure Male & $\begin{array}{l}92.14^{* * *} \\
(5.680)\end{array}$ & & $\begin{array}{c}54.52^{* * *} \\
(9.276)\end{array}$ & $\begin{array}{c}38.03^{* * *} \\
(7.901)\end{array}$ & \\
\hline$(\text { Log Leisure Male })^{2}$ & $\begin{array}{l}-8.540^{* * *} \\
(0.323)\end{array}$ & & $\begin{array}{c}-6.196^{* * *} \\
(0.573)\end{array}$ & $\begin{array}{c}-5.125^{* * *} \\
(0.585)\end{array}$ & \\
\hline Log Leisure $\times$ German Male & $\begin{array}{l}-0.817 \\
(0.495)\end{array}$ & & $\begin{array}{c}-0.902 \\
(1.142)\end{array}$ & $\begin{array}{c}0.365 \\
(0.973)\end{array}$ & \\
\hline Log Leisure Male $\times$ Age Male & $\begin{array}{l}-0.320^{* * *} \\
(0.0705)\end{array}$ & & $\begin{array}{c}-0.297^{* *} \\
(0.109)\end{array}$ & $\begin{array}{l}0.00263 \\
(0.0784)\end{array}$ & \\
\hline Log Leisure Male $\times$ Age Male $^{2}$ & $\begin{array}{l}0.00392^{* * *} \\
(0.000782)\end{array}$ & & $\begin{array}{l}0.00368^{* *} \\
(0.00123)\end{array}$ & $\begin{array}{c}0.000140 \\
(0.000922)\end{array}$ & \\
\hline Log Leisure Male $\times$ Disability I & $\begin{array}{l}0.994^{* * *} \\
(0.291)\end{array}$ & & $\begin{array}{l}1.255^{*} \\
(0.494)\end{array}$ & $\begin{array}{c}1.570^{* * *} \\
(0.422)\end{array}$ & \\
\hline Log Leisure Male $\times$ Disability II & $\begin{array}{l}1.815^{* * *} \\
(0.549)\end{array}$ & & $\begin{array}{l}2.171^{*} \\
(0.909)\end{array}$ & $\begin{array}{l}1.819^{\text {** }} \\
(0.599)\end{array}$ & \\
\hline Log Leisure Male $\times$ East & $\begin{array}{l}-13.80^{* * *} \\
(2.656)\end{array}$ & & $\begin{array}{c}-0.0987 \\
(0.686)\end{array}$ & $\begin{array}{l}-0.161 \\
(0.555)\end{array}$ & \\
\hline Male Part Time I & $\begin{array}{l}-3.497^{* * *} \\
(0.241)\end{array}$ & & $\begin{array}{c}-3.116^{* * *} \\
(0.389)\end{array}$ & $\begin{array}{c}-3.671^{* * *} \\
(0.341)\end{array}$ & \\
\hline Male Part Time II & $\begin{array}{l}-3.484^{* * *} \\
(0.106)\end{array}$ & & $\begin{array}{c}-3.299^{* * *} \\
(0.204)\end{array}$ & $\begin{array}{c}-3.398^{* * *} \\
(0.177)\end{array}$ & \\
\hline $\begin{array}{l}\text { Log Leisure Male } \times \text { Log Leisure Female } \\
\quad \times \text { German Male }\end{array}$ & $\begin{array}{l}-0.0293 \\
(0.115)\end{array}$ & & & & \\
\hline Log Leisure Male $\times$ Log Leisure Female & $\begin{array}{l}-0.785 \\
(0.422)\end{array}$ & & & & \\
\hline $\begin{array}{l}\text { Log Leisure Male } \times \text { Log Leisure Female } \\
\text { quad } \times \text { East }\end{array}$ & $\begin{array}{l}3.365^{* * *} \\
(0.658)\end{array}$ & & & & \\
\hline $\begin{array}{l}\text { Observations } \\
\text { Derivatives }\end{array}$ & 105,002 & 8,983 & 4,284 & 5,017 & 7,768 \\
\hline $\begin{array}{l}U_{y}>0 \\
U_{l f}>0 \\
U_{l m}>0\end{array}$ & $\begin{array}{l}97 \% \\
67 \% \\
100 \%\end{array}$ & $\begin{array}{l}91 \% \\
58 \%\end{array}$ & $100 \%$ & $76 \%$ & $\begin{array}{l}100 \% \\
73 \%\end{array}$ \\
\hline
\end{tabular}

Source: Source: Own calculations based on the SOEP v291 (2012) and a modified version of the STSM. 
Table 9: Average Welfare Changes under Different Welfare Weights.

\begin{tabular}{lccc}
\hline & Employment & Full-Time & Flat Tax \\
\hline$v=0$ & 84 & 492 & 688 \\
$v=0.5$ & 290 & 497 & 1313 \\
$v=1$ & 484 & 495 & 1856 \\
$v=1.5$ & 666 & 487 & 2359 \\
$v=2$ & 833 & 476 & 2865 \\
\hline
\end{tabular}

Source: Own calculations based on the SOEP v291 (2012) and a modified version of the STSM. 